\title{
A memória e o valor da síncope: da diferença do que ensinam os antigos e os modernos ${ }^{1}$
}

\author{
Sérgio Paulo Ribeiro de Freitas (UNICAMP, Campinas, SP) \\ c2sprf@udesc.br
}

\begin{abstract}
Resumo: A síncope é um tema privilegiado nos estudos da música popular que reaparece aqui em um conjunto de considerações que, marcado pelo viés dos saberes das velhas disciplinas de Contraponto e Harmonia, sublinham a interação e, principalmente, a inseparabilidade entre métrica (divisão, ritmo, acentuação, prosódia, etc.) e altura (notas, intervalos, relação dissonância-consonância, acordes, notas auxiliares, etc.) na apreciação crítica das figurações sincopadas. Na primeira parte percorre-se uma mínima memória da arte e da teoria da síncope na tradição ocidental culta para, na segunda parte, observar-se que, em medida tácita e sutil, resíduos dessa tradição afetam juízos de valor em alguns dos sincopados cenários da música popular atual.
\end{abstract}

Palavras-chave: síncope; análise musical; teoria e crítica da música popular.

\section{Memory and value of syncopation: on the difference between what the old and the modern teach}

Abstract: Syncopation is a privileged issue in popular music studies that reappears here in a number of considerations that, marked by the bias of knowledge of the old disciplines of Counterpoint and Harmony, underline the interaction and, especially, the inseparability between metric (division, rhythm, accentuation, prosody, etc.) and pitches (notes, intervals, dissonance-consonance relationship, chords, auxiliary notes, etc.) in a critical analysis of the figures of syncopation. The first part covers up a minimum memory of the art and theory of syncopation in the Western erudite tradition, so that, in the second part, it can be noted that, in tacit and subtle manner, residues of this tradition can affect the value judgment in some of the syncopated worlds of popular music today.

Keywords: syncopation; musical analysis; theory and criticism of popular music.

\author{
"Mas, porque omitiste a ligadura? Já disse que não devemos perder \\ qualquer ocasião para usar uma síncope. \\ Johann Joseph Fux, 1725 (FUX, 1971, p. 60).
}

\section{1 - Introdução: da síncope letrada e sua coexistência em cenários conflituosos}

A síncope é assunto que se destaca nos "múltiplos discursos" que, como mapeou TRAVASSOS (2005), confirmam a condição da "música popular como tema privilegiado da cultura brasileira".2 Procurando conversa com tais discursos o presente texto argumenta: a síncope é uma questão de rítmica, mas é também, inseparavelmente, uma questão de alturas. Tal "ponto de escuta", característico dos antigos, especializados e consideravelmente privilegiados textos e cursos formais do Contraponto e da Harmonia, será reouvido aqui num percurso que delineia marcos da síncope letrada desde os finais do século XV até os inícios do XIX. Sem deixar de valorizar a sempre lembrada presença da síncope na música urbana da viragem para o século XX até nossos dias, a intenção de uma re-escuta assim é sublinhar que tais artesanalidades cultas, instituídas em cenários embaralhados, conflituosos, plenos de interações negociadas e imprevisíveis, também se misturam nesse "um bocadinho de cada coisa" que compõem a sincopada música popular que podemos escutar hoje. ${ }^{3}$

Nos centros musicais cultos da velha Europa, um lugar capital de onde partiu ainda jovem (em formação) para conquistar novos mundos, a síncope veio se consolidando como uma figuração de alto valor artístico na música contrapontística culta da renascença. Quando madura, essa será a síncope canônica, a síncope de catequização 
(cristã, ocidentalizante): a síncope de escola que no geral se aprende, desde o iluminismo, através da codificação fuxiana inspirada no modelo quinhentista observado na música de Palestrina. Por conta de sua primeira datação (séculos XIV ao XVI), a síncope já possui vasta cultura artística e teórica quando a incipiente tonalidade harmônica ensaia seus primeiros passos. Assim, se sabe, a síncope do stile antico antecede a sistematização moderno-contemporânea dos compassos. Sem as barras do compasso, mas não sem métrica, o deslocamento rítmico - que faz a fama das figuras de síncope - se observa nessa música pré-tonal, basicamente, nos deslocamentos dos acentos do texto cantado (prosódia) e nos desvios da pulsação pendular (cujo padrão se constitui da alternância periódica da consonância no tempo forte contra a dissonância no tempo fraco), respeitando-se as convenções do andamento e das subdivisões rítmicas impostas pelos estilos eruditos da polifonia vocal europeia. ${ }^{4}$

Se, no nível da artesanalidade, a noção pré-tonal de síncope pertence a uma concepção de música que não pôde imaginar o divórcio das alturas (notas e intervalos) de seus desenhos rítmicos, em outro nível, tal música também não pôde existir fora de um cenário ele próprio sincopado. 0 mundo onde essa síncope modal, vocal e contrapontística convive, interage e abre espaço para a síncope tonal, instrumental e harmônica é o mundo onde a Europa de um Tinctoris, passando por um Palestrina, se transforma na Europa de um Rameau, de um J. S. Bach e de um Beethoven. É também o mundo onde se descobre que é possivel forjar o Novo Mundo (Novi Orbis). Um cenário vivo, amplo, intenso, que sofre ligaduras de toda ordem: musicais, sociais, culturais, linguísticas, econômicas, científicas, mitológicas, filosóficas, etc.

Parte desse mundo que assiste o florescimento da síncope pós-modal na Europa cosmopolita assiste também "a revolução mais radical da história da música ocidental" (HARNONCOURT, 1993, p.27): a conversão da música determinada pelos cânones do Stylus gravis (primeira prática ou stile ântico) para a música do Stilus luxurians (segunda prática ou stile moderno). Re-sinalizar as célebres tensões entre as duas práticas é necessário numa revisão que deseje destacar a presença da síncope colonizadora que se fez ouvir nas circunvizinhanças das missões cristãs interferindo massivamente na primeira idade da música popular que veio se inventando em paragens do Caribe, Cuba, México, EUA, Jamaica, Haiti, Bolívia, Colômbia, Paraguai, Uruguai, Venezuela, Chile, Argentina, Brasil, etc. Territórios protetorados que se fazem reconhecer hoje por sua típica (enraizada, nativa, natural, pura, peculiar, característica, exótica ou estereotipada) maneira sincopada de fazer música. ${ }^{5}$

Em tais "regiões periféricas à Europa ocidental - ideal de civilização e fonte de modelos culturais para as sociedades em sua órbita" (TRAVASSOS, 2000, p.24), a exuberante síncope popular contemporânea (pós-segunda prática, pós-barroca, pós-clássica, pós-romântica, pós-colonial, etc.) possui qualidades que superam em muito tanto a gravidade das síncopes do contraponto quanto os preceitos modernos da bela ciência da harmonia (dita hoje tradicional). Com isso, mesmo desconsiderando fatores históricos e sócio-culturais, tal exuberância "puramente musical" já é capaz de invisibilizar o fato de que a síncope pré-século XIX também compõe aquilo que somos hoje. A tal ponto que, para um "ponto de escuta" musicológico mais incisivo: a síncope é "uma das mais importantes fórmulas rítmicas surgidas nas Américas no século dezenove" e "pode-se afirmar que a síncope caracteristica desenvolvida nas Américas não tem relação nenhuma com a antiga sincope europeia" (CANÇAD0, 2000, p.6).

Tal invisibilidade pode tornar-se um vício de método, cercear consideravelmente nosso alcance crítico e comprometer nossas estimativas da profundidade, duração e repercussão dos processos de sincretismo que o nosso velho Novo Mundo atravessa nas diferentes fases da sua interminável descoberta. Não valorizar a presença do stile di Palestrina - considerando que "a música de Palestrina, devido ao seu caráter estritamente religioso e seu conservadorismo, tornou-se o modelo ideal para a Contra-Reforma" (CARVALH0, 2000, p.49-50) - pode nos levar a não ouvir a presença da música da Igreja, essa superestrutura distribuidora de síncopes que, naqueles anos da idade moderna (antecedendo e depois convivendo com as menos lembradas músicas da ópera e das corporações militares e com a, sempre citada, sincopada "música das danças europeias de salão") foi uma personagem institucional com grande poder de barganha na mixagem negociada que veio formando o ouvido musical destes lugares ditos novos e populares. ${ }^{6}$

Nas disputas do moderno contra o antigo, a sincope é um dispositivo caro aos antigos que os modernos vão desapropriar e os contemporâneos vão transformar. São muitos os registros para a apreciação desses apreços, apropriações e reinvenções e, considerando que síncope "designa um conceito criado pelos teóricos da música erudita ocidental [...], talvez não seja inútil examinar como tal conceito foi formulado por estes" (SANDRONI, 2001, p.20).

Mesmo que, no presente artigo, o entendimento de quem são esses "teóricos da música erudita ocidental" difira do elenco já referenciado por Sandroni, e mesmo que a diacronia da síncope, com saltos e lacunas, seja re-delineada a seguir de maneira muito geral, defende-se aqui a divulgação de um patrimônio conceitual e artístico (da humanidade) que, grosso modo, ainda se encontra formalmente alienado dos limites precondicionados (usualmente sincrônicos e paramétricos) que vamos impondo ao campo da música popular no âmbito acadêmico.

Algum apossamento desse legado histórico, teórico, técnico e culto (e por isso supostamente "desinteressante" para alguns dos "múltiplos discursos" que cuidam do "nosso popular") oportuniza também observar uma espécie de tra- 
jetória por inflação (aumento excessivo, superabundância com desvalorização, banalização, etc.). Notar tal inflação - ou "diluição" no sentido de Pound (1986, p.42-43), ou ainda "falsificação" no sentido de Adorno (2004, p.36-38) - em dispositivos musicais como a síncope é tarefa meandrosa e imprecisa, mas pode ser útil nos estudos que abordam as interações contínuas e prolongadas que, praticadas por muita gente e em vários lugares ao mesmo tempo, contribuíram com a formação e consolidação dessa música que aprendemos a chamar de popular.

\section{2 - Sobre a síncope do estilo antigo: quando o muito longe se mostra muito perto ${ }^{7}$}

Em seu Kontrapunkt, LA MOTTE prefere eleger Josquin des Prés (c.1440-1521) como o "capítulo fundamental do contraponto" (e não Palestrina como, desde Fux, se tornou o mais usual). Considerando os méritos musicais de Josquin (e de outros compositores nascidos no século XV, tais como Ockeghem e Isaak) e as diversas motivações de La Motte, esta re-datação da disciplina permite observar algo da arte e normalização da síncope europeia em fases ainda anteriores aos anos de 1500. Anteriores assim aos tantos efeitos das misturas e contra-misturas cada vez mais inevitáveis e densas resultantes das tensões provocadas por ocorrências coexistentes e incisivas como a Reforma Protestante, o Atlântico Negro e as conquistas do Novo Mundo que - em enredos traumáticos, difíceis de descrever ou mesmo de imaginar - vão desterritorializar e re-significar a síncope para sempre.

Ratificando a convicção de que na teoria culta europeia, desde a mais elementar definição, na síncope as alturas não se separam da métrica, La Motte (1998, p.76-89) argumenta: "a síncope (ou retardo) é uma dissonância que conquista o tempo forte". Assim, acompanhar a trajetória da síncope é também "contemplar a emancipação da dissonância":
Em Perotin [c.1160-1236] eram as consonâncias perfeitas [unissono, $8^{a}, 5^{a}$ e $4^{a}$ s] as que regiam os tempos fortes. Com os neerlandeses, foram as consonâncias imperfeitas [ $3^{\text {as }}$ e $6^{\mathrm{a}} \mathrm{s}$ ], as triades maior e menor e 0 acorde de sexta [primeira inversão], as que conquistaram para si esta posição. A dissonância também vai abrindo caminho em direção aos tempos acentuados e, nesta posição, a dissonância é percebida como um acontecimento sonoro, da mesma maneira que a dissonância de passagem [colocada no tempo fraco] que se utiliza como uma via para ir de uma consonância a outra. Contudo, a dissonância se adentra nos tempos fortes com extremada precaução. Em Josquim, as regras para o tratamento das dissonâncias do tempo forte são extremamente rígidas [...]. Salvando-se umas poucas exceções, só existem três formas [Ex.1], cada uma delas com duas variantes (LA MOTTE, 1998, p.76).

Observa-se ainda que na música de Josquin e seus contemporâneos a síncope não se emprega em qualquer lugar nem o tempo todo. Essa estimada "dissonância acentuada" tinha um uso mais reservado, uma função específica de "figura construtora de forma".

Se quisermos nos aproximar da música de Josquin temos que estudar o papel de construtoras de forma que desempenham as dissonâncias acentuadas. A saber: essa forma de dissonância aparece em meio do contexto musical de modo manifestadamente singular. Na maior parte dos casos se assinala com ela o final de uma frase ou de uma passagem (LA MOTTE, 1998, p.78).

Culto e comedido esse uso da dissonância sincopada como figura cadencial já está normalizado em 1477 no Liber de arte contrapuncti de Johannes Tinctoris (c.14351511): essa é "a suspensão sincopada", "a sincopação descendente para uma cadência que é usualmente encontrada na polifonia da metade e final do século XV" (TOMLINSON, 1998, p.403). ${ }^{8}$ La Motte (1998, p.78) ilustra essa função de "fixação quase tonal", esse papel de "conferir estabilidade momentânea", com uma bela seleção de fragmentos onde as figuras de síncope ornamentam finalizações sobre diferentes graus dos modos. 0 Ex.2 reproduz algumas dessas pontuações.

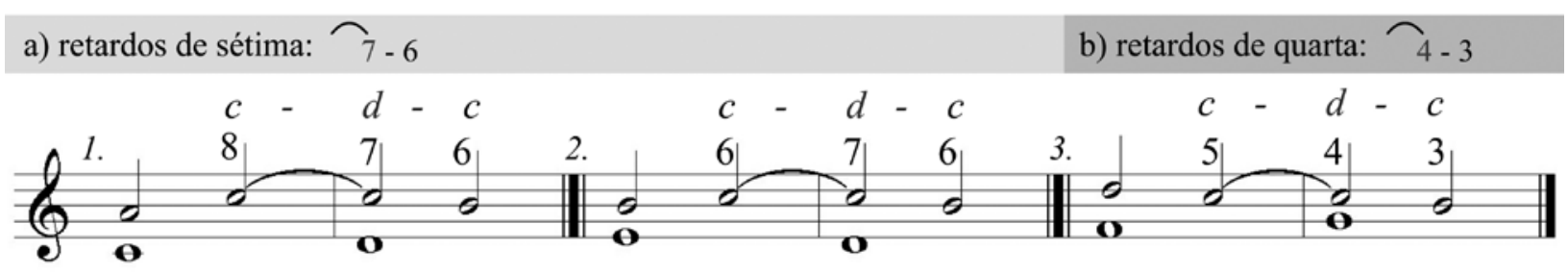

c) retardos de segunda: $\frown 2-3$

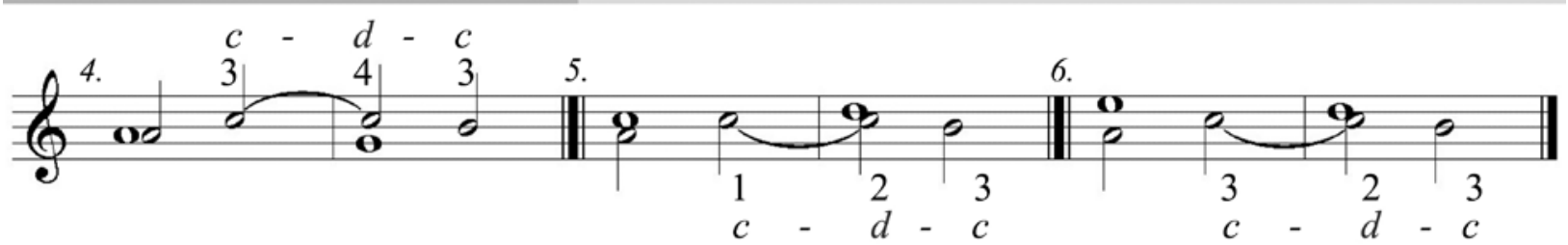

Ex.1 - Tipificação das formas básicas das figuras de síncope em Josquin. ${ }^{9}$ 


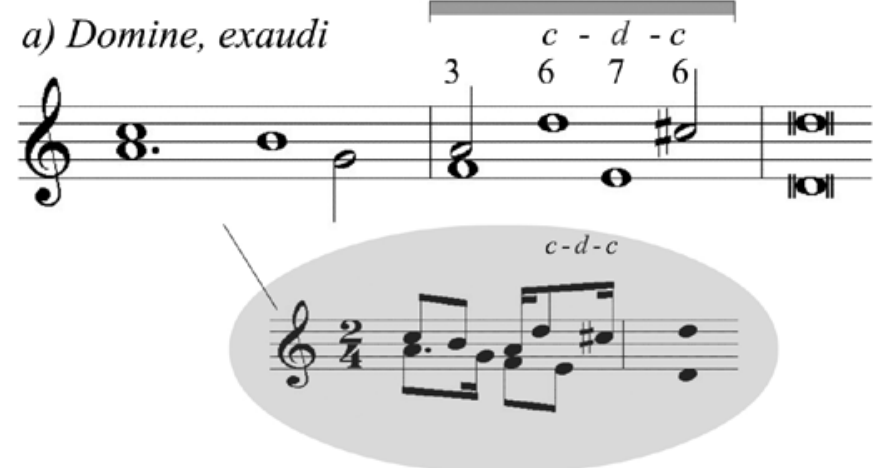

b) Ecce tu pulchra es

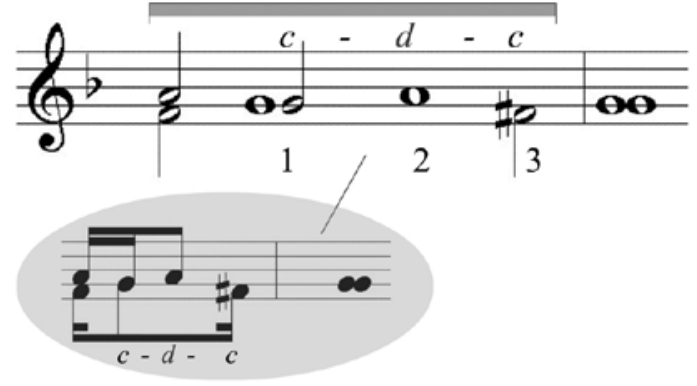

c) Pange lingua
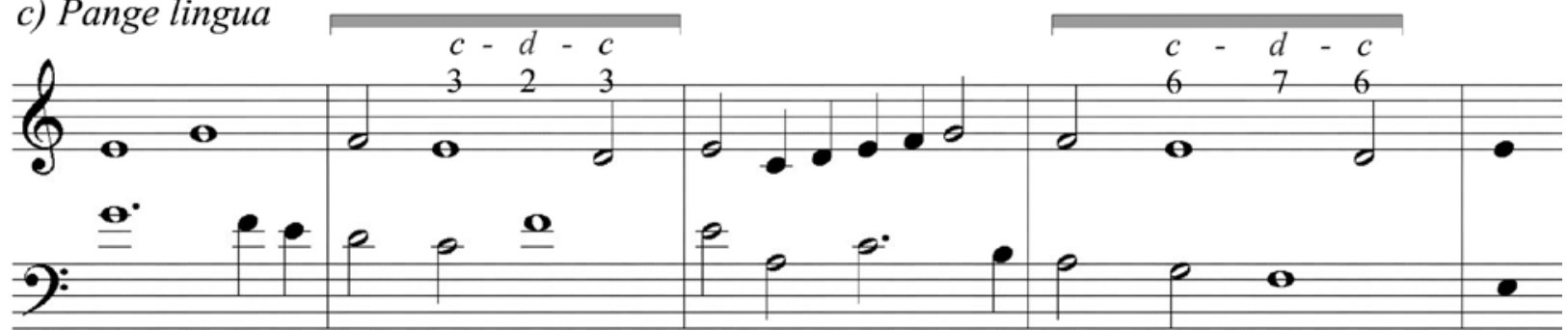

\section{d) O bone et dulcissime Jesu}

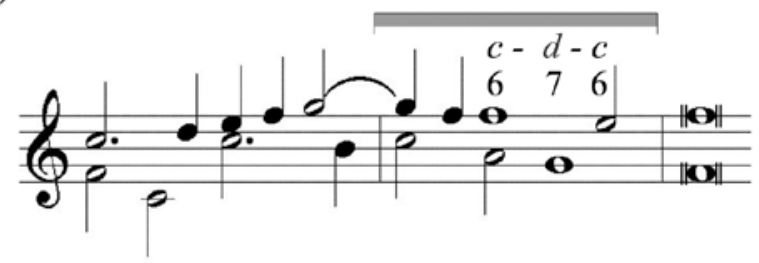

e) Domine, exaudi

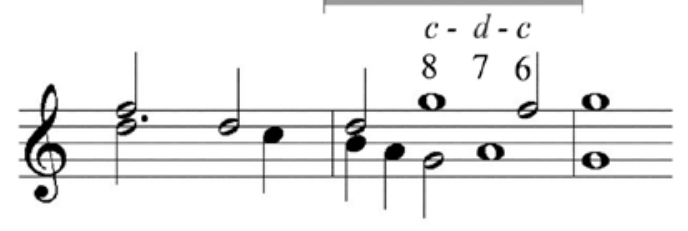

Ex.2 - A síncope como figura de dissonância em cláusulas escolhidas nas obras de Josquin. ${ }^{10}$

A partir desse marco renascentista - que nos ensina que "a força expressiva e a beleza da dissonância acentuada [retardo ou suspensão] se baseiam em parte em sua qualidade de sincope" (FORNER e WILBRANDT, 1993, p.128) - essa conjunção melos-rythmos vai conhecer um vasto percurso artístico e teórico. Mas no essencial estará sempre distendendo (inflacionando) o limite mecânicoexpressivo que podemos apreender aqui. 0 Ex.3 traz uma sintese da fortuna crítico-teórica da síncope. Um concentrado de termos, conceitos e entendimentos considerados importantes nas definições que, salvo diferenças pontuais, encontramos em diversos tratados e manuais. Grosso modo, esta normalização serve como referência preliminar para a observação geral das síncopes na música culta europeia dos séculos XVI ao XIX e também das síncopes das músicas populares do século XX.

Entre a geração de Tinctoris (†1511) e Josquin (†1521) e a de Palestrina (†1594), surge um dos grandes referenciais do antigo: o Istitutioni harmoniche (1558 e 1573) do teórico, compositor e clérigo franciscano Gioseffe Zarlino (1517-1590). Zarlino cuida da síncope em várias passagens do Istitutioni... mostrando que o dispositivo possui notável papel na música de seu tempo. 0 Ex.4, extraído da terceira parte do Istitutioni..., discute três diferentes casos de sincope. No primeiro temos a sincopação -9-8, i.e., a modernizadora resolução da dis- sonância acentuada em consonância justa. No segundo a ligadura -9-8 vem seguida da tradicional -7-6, uma espécie de síncope de compensação que atenua o grau de perfeição da oitava. E o terceiro apresenta uma sequência de sincopes onde a sonoridade -9-8 se encadeia por elisão (inflação por justaposição) com a sincope -7-6.

Dando um passo na história o Ex.5 traz uma mínima amostragem da síncope na engenharia contrapontística de Giovanni Pierluigi da Palestrina (1525-1594). Conforme os estudos sobre o uso da dissonância em Palestrina publicados por JEPPESEN em 1946, a síncope (a dissonância acentuada) ocupa importância evidente no tecido palestriniano. Jeppesen demonstra tal qualidade quantitativamente: em 1489, 5 compassos examinados nos Cruxifixus de 15 Missarum liber (livros de Missas) de Palestrina, são encontrados 1163 síncopes dissonantes, 1006 notas de passagem e 315 bordaduras, perfazendo um total de 20,85\% de dissonâncias. Examinando 0 mesma quantidade de compassos nos Benedictus desses 15 livros, Jeppesen encontrou 955 sincopes dissonantes, 1469 notas de passagem e 445 bordaduras, num total de 24,08\% de dissonâncias (JEPPESEN, 1992, p.284-285).

0 Ex.5b mostra uma resolução ornamentada, indício de que, por inflação, os embelezamentos da desculpa (re- 
Essa nota de onde parte a ligadura recebe o nome de preparação

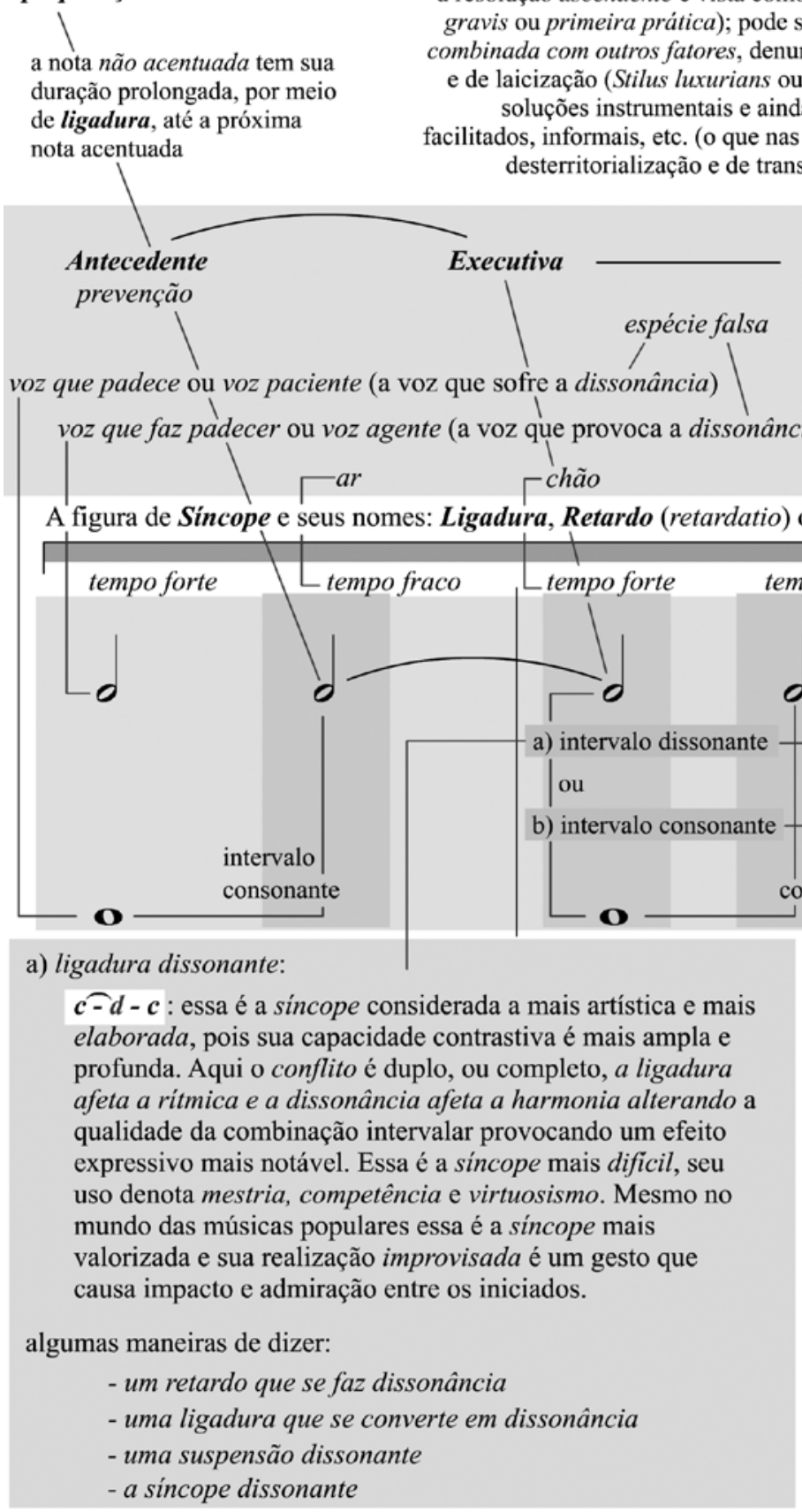

A resolução da dissonância deve ser descendente, por grau conjunto e, preferencialmente, sobre consonâncias imperfeitas

a resolução ascendente é vista como um erro no contraponto vocal de estilo rigoroso (o Stylus gravis ou primeira prática); pode ser aceita como coisa incomum e, por fim, é uma ação que, combinada com outros fatores, denuncia barroquismo, conota estilos em fase de modernização laicização (Stilus luxurians ou segunda prática), estilos já modernos influenciados pelas

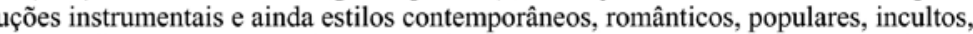
nas disputas simbólicas e nos processos de re-significação, de ação, pode não ser algo necessariamente negativo). I

Consecutiva (ou Conseqüente) resolução: desculpa, sahida ou desempenho; desligar

a) ligadura precisa

b) ligadura voluntária alguns termos usados em tratados brasileiros e portugueses nos séculos XVIII e XIX:

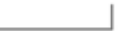

\section{ou arbitrária \\ $\left.\right|_{\text {Iuspensa }}$}

Ex.3 - Uma sintese da normalização tradicional da figura de síncope."

solução) vão se tornar cada vez mais sofisticados. Para comentar essa intensificação da ornamentação na parte final da síncope OWEN prepara dois grupos de figurações hipotéticas. No primeiro (Ex.6 a, b, c, d, e) aparecem ornamentações da resolução típicas da suspensão préséculo XVII (OWEN, 1992, p.47). E o segundo (Ex.6 f, g, h, i) adianta ornamentações que se consolidaram a partir do século XVIII (OWEN, 1992, p.178).

Contudo, antes de adentrarmos de vez no período da síncope tonal, importa notar que estes poucos fragmentos da síncope renascentista já são suficientes para que a lição da "potência dos contrários" (ARISTÓTELES, 1998, p.144) - lição de fundo da música (e da cultura) ocidental - se reafirme: "A beleza é multíplice" escreveu Giordano Bruno (1548-1600), o famoso teólogo, filósofo, escritor, frade italiano e contemporâneo de Palestrina:

Entre coisas completamente similares, não existe beleza. [...] A beleza se revela no engate das partes distintas: a beleza de tudo consiste na própria variedade. [...] 0 princípio, o meio e o fim, 0 nascimento, o aumento e a perfeição de tudo o quanto vemos resulta de contrários, por contrários, em contrários e para os contrários (BRUNO apud TATARKIEWICZ, 1991, p.374 e 377). 


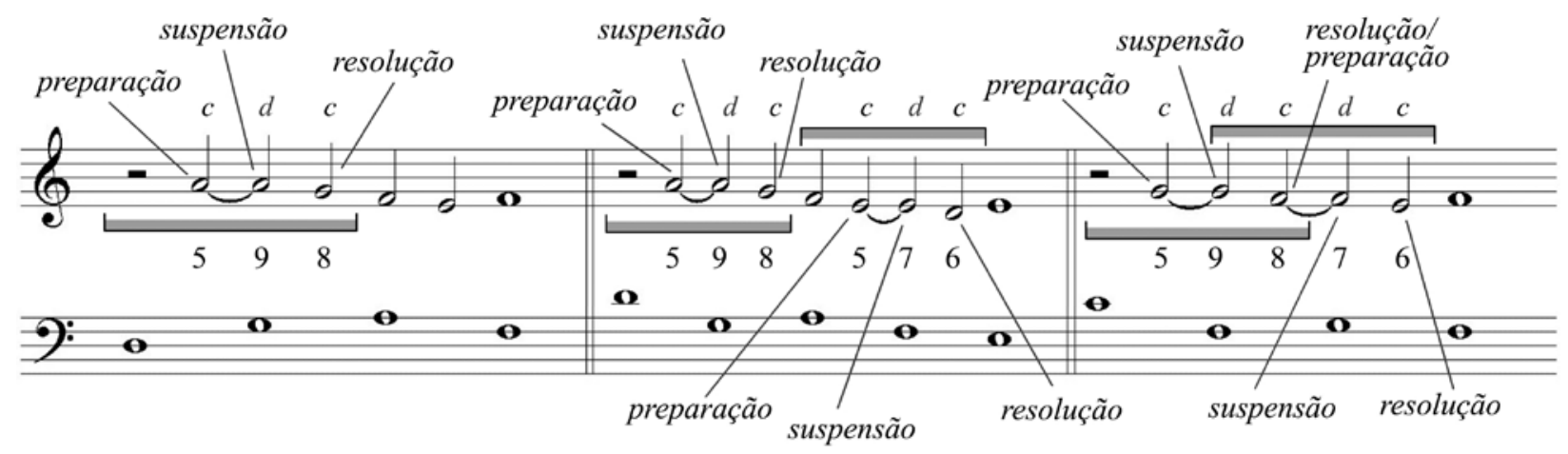

Ex.4 - Figuras de síncope da p.198 do Istitutioni harmoniche de Zarlino: Sincope ottimamente risolte.

a) Tu nobis dona fontem lacrymarum

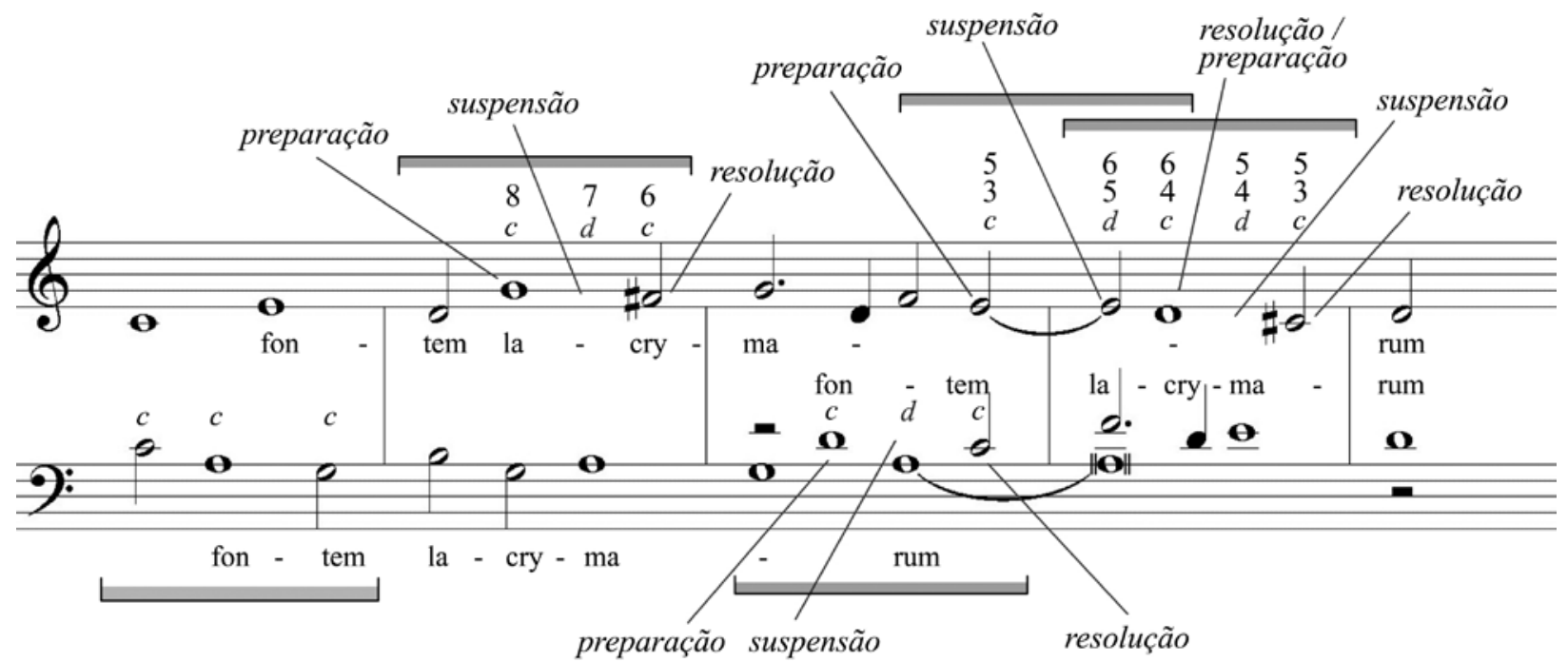

b) Sicut cervus

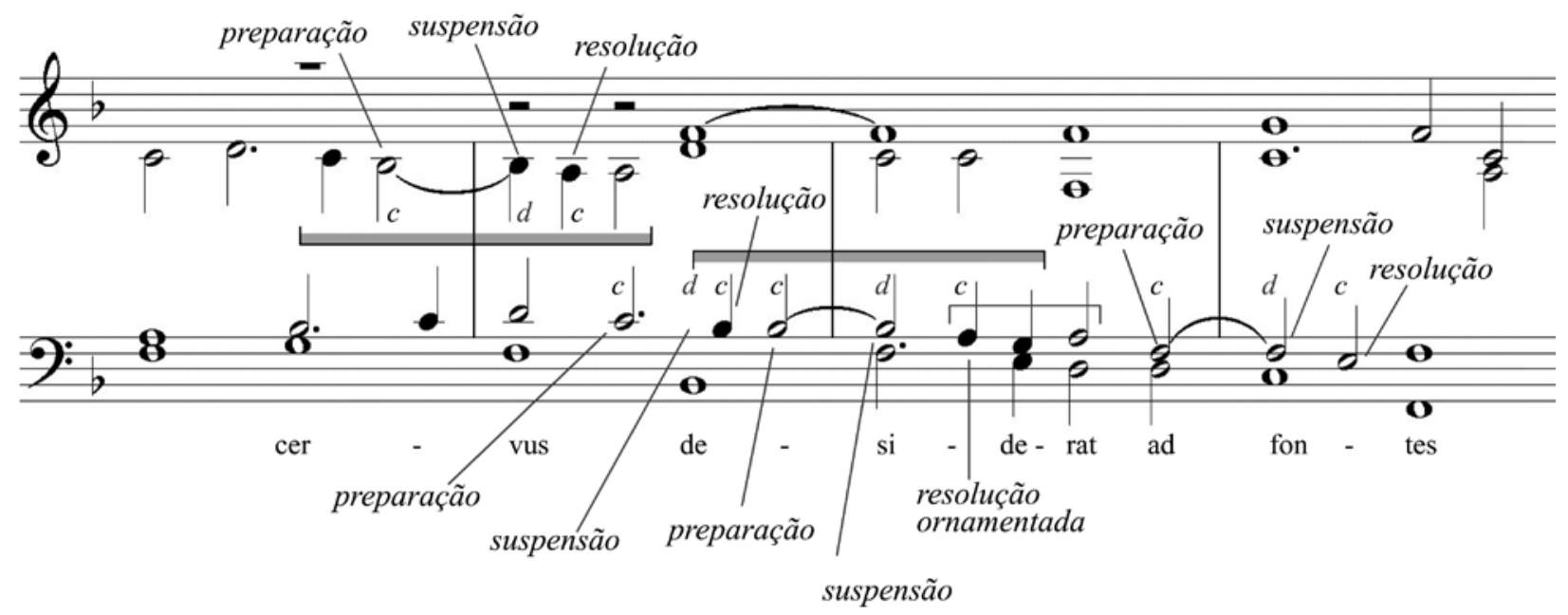

Ex.5 - Amostragem de figuras de síncope em dois fragmentos de obras de Palestrina. ${ }^{12}$ 
a)

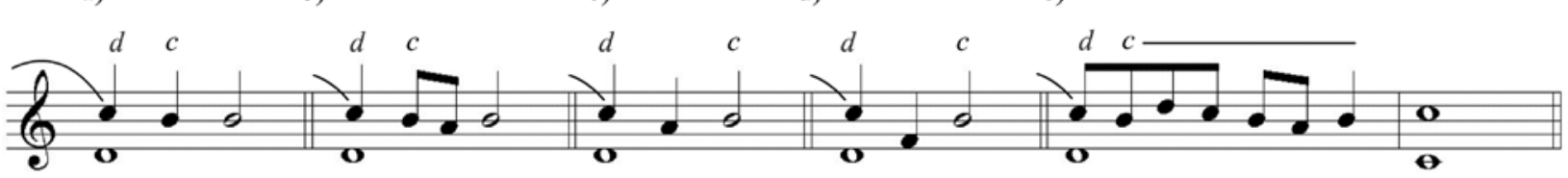

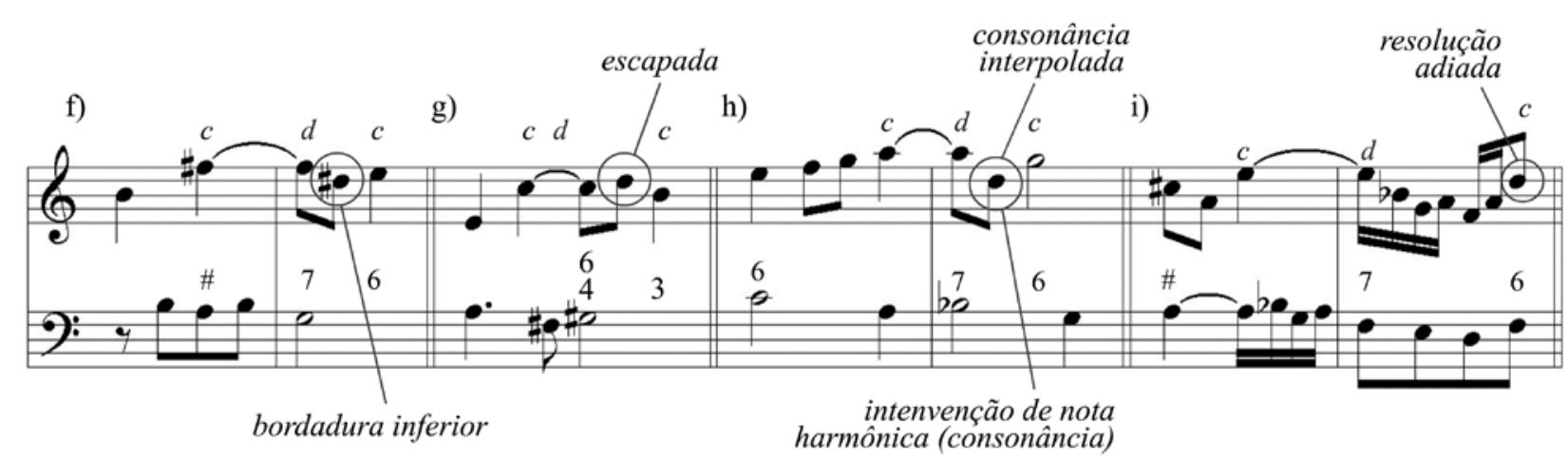

Ex.6 - Ornamentação da resolução (desculpa) da suspensão segundo Owen.
Na teoria de Zarlino - comenta ABDOUNUR (1999, p.43) a música, como a pintura, torna-se mais arrebatadora "se for pintada com várias cores". A arte dos sons "proporcionará maior prazer aos sentidos se proceder como a própria natureza, que gera seres semelhantes de uma mesma espécie, mas contrapõe essa semelhança introduzindo diferenças e traços variantes infinitos". Mestre do Stylus gravis, Zarlino defende que a perfeição resulta do confronto de elementos distintos, discordantes e contrários, possuindo em suas partes, proporções, movimentos e tessituras variadas. Entende que a consonância precisa ser contraposta, valorizada pela oposição da dissonância: a harmonia não se dá entre coisas completamente semelhantes, "isso precisa até ser evitado" (i.e., proibido por regras) "em nome de poupar o ouvido da insistência dessa perfeição". Mais tarde vamos ouvir SCHOENBERG (2001b, p.58) redizer: "as expressões consonância e dissonância, usadas como antíteses, são falsas". E DAHLHAUS (1990, p.21) reiterar: "o pré-requisito de uma harmonia é a varietà ou a diversità"

Assim - artisticamente, tradicionalmente, eurocentricamente -, é um equivoco supor que "dissonâncias sincopadas" são aquilo "que não se pode fazer". Sincopar não é algo "do outro", não é um "não-belo" ou uma "discordância" ingenuamente entendida como uma escolha que, jogando contra o patrimônio, seria "indesejável", "proibida" ou mesmo uma "contravenção ao ocidental". 0 conceito é bem mais nuançado e dinâmico. "Dissonâncias sincopadas" são forças de movimento e contraste, são estímulos contrários, medidas de equilibrio, dinamismo e risco que dotam o discurso de expressividade, agudeza, engenho e interesse. 0 fato do acento dissonante ser fruto de uma relação (e não algo em si) não se confunde com "cacofonia" ou "anormalidade". Dissonância e consonância, metro e contra-metro, se pertencem: um não se realiza plenamente sem o outro. Entre o dito e o não dito, os "gênios" da música culta europeia são justamente aqueles que dominam a arte da "conjunção dos opostos" (TOMÁS, 2002, p.97). Arte que se realiza no manejo das síncopes e de tantos outros truques de deslocamento, distorção, desencaixamento e contra-norma. A norma (o Canon, a Lei), como afirmava Tinctoris em 1477 em sua famosa oitava (e última) "regra de uma condução de vozes ideal" é: "que em todas as vozes contrapontísticas reine a diversidade melódica, rítmica e de qualquer tipo", "a variedade é exigência urgentíssima em todo contraponto"(TINCTORIS apud FORNER e WILBRANDT, 1993, p.25).

\section{3 - Normalização da síncope no estilo moderno}

Um belo registro dos inícios da era tonal, mostrando que 150 anos depois de Tinctoris a síncope era tema de conversas cultas (e não um pormenor de técnica restrito aos especializados), se lê no Compendium musicae de 1618 escrito ainda em Latim por um jovem, educado entre jesuítas, que se tornou conhecido como o filósofo René Descartes (1596-1650).

A sincope se produz quando, em uma voz, o final de uma nota se ouve ao mesmo tempo em que o começo de uma outra nota da parte contrária [outra voz]. Como se pode ver no exemplo exposto [Ex.7], onde o último tempo da nota B está em dissonância com 0 início da nota $C$; contudo, isto se tolera porque a lembrança da nota $A$ se conserva nos ouvidos. $E_{1}$ assim, a $B$ com respeito à $C$, é só uma voz relativa na qual se suportam as dissonâncias. Mais ainda, a variedade destas faz que as consonâncias, entre as quais estão situadas, se ouçam melhor e inclusive provoquem a atenção, pois, quando se ouve a dissonância $B C$, aumenta a expectativa $e_{\text {, }}$ em certa medida, se suspende o juízo sobre a doçura da sinfonia até que se chegue à nota $D$, na qual se satisfaz mais ao ouvido e, todavia se lhe dá maior satisfação na nota E. Com esta, depois 
de que o final da nota $D$ manteve a atenção, a nota $F$, que vem imediatamente após, forma uma perfeita consonância, pois é uma oitava. Estas síncopes são utilizadas nas cadências, porque agrada mais o que finalmente chega após ter sido esperado durante muito tempo; e por isso, depois de ter ouvido uma dissonância, o ouvido descansa melhor em uma consonância perfeita ou no unissono (DESCARTES, 1992, p.108-109).

0 Ex.8 ilustra a sincopação idealizada por Johann Joseph Fux (1660-1741) cento e poucos anos depois do Compendium de Descartes. Nesta espécie de escritura - que passou a ser a norma escolar do que é a síncope no contraponto modal renascentista - o tal processo de inflação se evidencia. A função cadencial da síncope se diluiu e, seja por razões de eficiência didática ou pelo distanciamento histórico e geográfico, o aprendiz, afastando-se da arte dos antigos mestres da síncope, deve se preocupar menos com as funções construtoras de forma e se esforçar ao máximo para encontrar o maior número possivel de ligaduras. ${ }^{14}$

Em 1725, nos diálogos do Gradus ad Parnassum, Fux cuida da síncope na "Lectio quarta": "a quarta espécie do contraponto"

é chamada ligadura ou síncope, e pode ser consonante ou dissonante. A ligadura consonante resulta quando as duas mínimas, a no arsis [tempo fraco] e a no thesis [tempo forte] são consonantes. [...] A ligadura dissonante resulta quando a mínima no arsis é consonante (que deve sempre ser o caso), a mínima no thesis, contudo, é dissonante (FUX, 1971, p.55).
Pouco antes, em 1722, Jean-Philippe Rameau (16821764) também destacou a síncope em seu Traité de I'harmonie. No Livro 3 ("princípios de composição"), a síncope dá título ao Artigo 7, para o qual RAMEAU (1986, p.296-299) escreve um hipotético trecho musical (Ex.9) ilustrando várias situações de síncope. ${ }^{15}$ Esse trecho tem interesse teórico, pois, mesmo se mantendo fiel aos números do contraponto e do baixo cifrado, concentra potencialidades bastante avançadas (inflacionadas) em relação ao que foi a antiga síncope de linhagem francoflamenga. Pelos números podemos ver que algumas ligaduras são efeitos rítmicos (cifradas com 3, 6, 5 e 8, ou seja, são consonâncias) enquanto que outras mostram tensões notáveis: a ligadura já parte de intervalo dissonante (o trítono, 4\# ocupando posição de preparação!); a resolução do intervalo dissonante (4\#) se dá na outra voz (baixo); o intervalo dissonante (2) se intromete na posição métrica de resolução; a voz que provocou a dissonância se movimenta por grau ascendente (4\# 6) ou mesmo salta (2 6); o último 7, ao se resolver em um 5, ilustra também a ousada possibilidade de uma desculpa (resolução) cair sobre uma consonância perfeita, o que seria proibido no estilo polifônico rigoroso (CARVALHO, 2000, p.90; LA MOTTE, 1998, p.76-77). Definitivamente 0 moderno Rameau não é mais um professor de contraponto modal do século XVI, e muitas das licenças sugeridas nesse trecho só se tornaram arte na música dos finais do século XVIII e ao longo do século XIX.
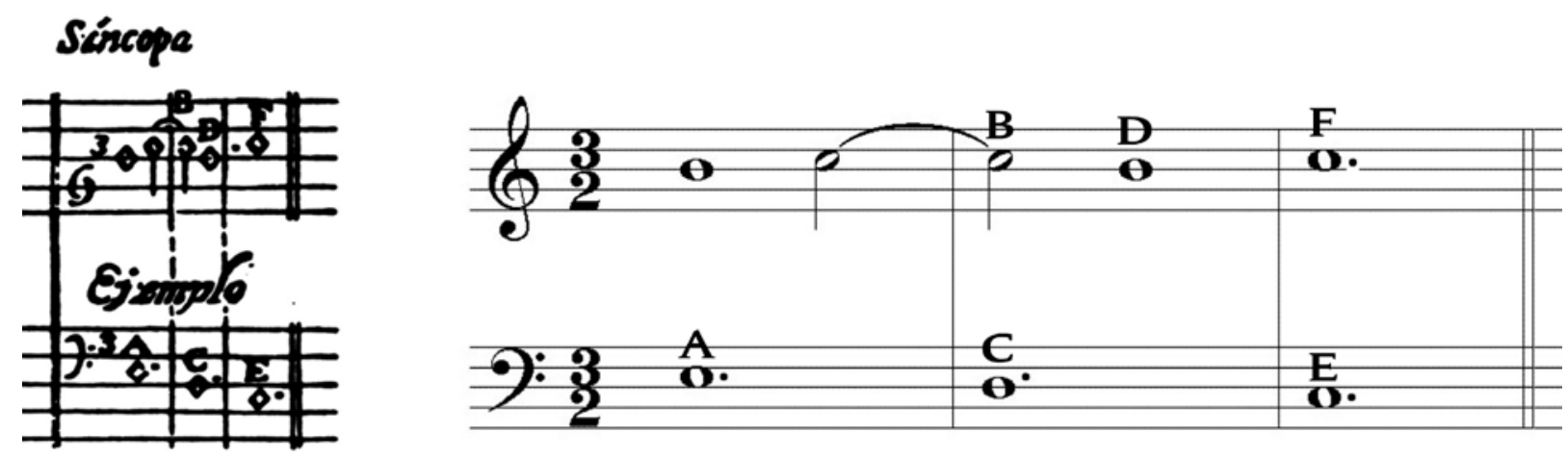

Ex.7 - A síncope segundo Descartes no Compendium musicae de 1618.

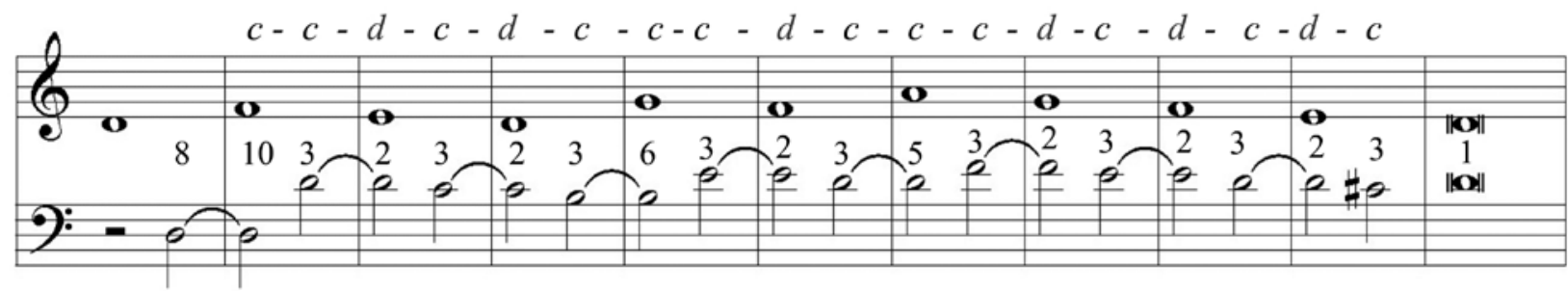

Ex.8 - Síncopes no Gradus ad Parnassum de Johann Fux (1971, p.61). 
Implicado com Rameau (e com a "Harmonia", emblemas de um estado social causador dos males da condição humana) o philosophe-musicien Jean-Jacques Rousseau (1712-1778) não deixou faltar um verbete para a "Syncope" no Dictionnaire de musique que publicou em 1768:

Síncope é a prolongação sobre o tempo forte de um som começado em tempo fraco; assim toda nota sincopada está em contratempo, e toda sucessão de notas sincopadas é uma marcha em contratempo. [...] A síncope tem seus usos na melodia para a expressão e o goût du chant; contudo sua principal utilidade está na harmonia para a prática das dissonâncias. A primeira parte da síncope serve como preparação: a dissonância se ataca na segunda; e numa sucessão de dissonâncias, a primeira parte da sincopa seguinte serve, ao mesmo tempo, para salvar a dissonância que precede e para preparar a que segue. [...] 0 senhor Rameau pretende que esta palavra derive do conflito dos sons que se entrechocam de alguma maneira na dissonância; porém as sincopas são anteriores à nossa harmonia, e muitos casos existem de síncopes sem dissonância (ROUSSEAU, 2007, p.368-369). ${ }^{16}$

Outro letrado que marcou a teoria musical na segunda metade do século XVIII foi Johann Philipp Kirnberger (1721-1783). Como uma espécie de prenúncio da era clássica seu trabalho é considerado uma síntese que reúne e reavalia a antiga tradição contrapontística, a arte do baixo contínuo de viés bachiano e as modernas ideias do baixo fundamental de Rameau (KIRNBERGER, 1979; LESTER, 2006, p.773; WASON, 2006, p.57). Em 1773, ocupado com os verdadeiros princípios para a prática da harmonia, Kirnberger enfrentou sistematicamente as suspensões dissonantes deixando um registro detalhado (minimamente referenciado no Ex.10) de como músicos de então poderiam entender, explicar e cifrar (numa dis- pendiosa inflação de números) o fenômeno inflacionado das ligaduras em uma, duas, três ou mesmo quatro vozes.

Nesse mesmo período (séculos XVII e XVIII), no vasto campo das figuras retóricas da música barroca alemã - a cultura musical matizada pelo viés reformista luterano -, a síncope tem lugar assegurado no conjunto das "figuras de dissonância e deslocamento" (BARTEL, 1997, p.446), ou "figuras de dissonância que afetam a harmonia e a condução de vozes" (LÓPEZ-CANO, 2000, p.167-168). Vale notar que Josquin também é referência para o mundo luterano, pois, por sua mestria, controle e ordenação dos recursos musicais "esse primeiro músico de expressão moderna" (LA MOTTE, 1998, p.xi) personifica uma aspiração nascida já

\begin{abstract}
nos primórdios da época burguesa, de "compreender" com critério de ordem tudo o que constitui o fenômeno musical e de resolver a essência mágica da música na racionalidade humana. Lutero chama Josquin [...] "o mestre das notas que devem ter feito o que ele queria, enquanto os outros mestres da música devem fazer o que as notas queriam". Dispor conscientemente de um material natural significa a emancipação do homem com respeito à coação natural da música e a submissão da natureza aos fins humanos (ADORNO, 2004, p.57).
\end{abstract}

Segundo BARTEL (1997, p.396-405), a síncope (syncopatio ou ligatura), uma suspensão com ou sem uma dissonância resultante, é um dos mais antigos dispositivos descritos pelos teóricos como um dos principais meios de formar e embelezar uma composição. ${ }^{19}$ Esse "ponto de escuta" da síncope foi registrado por diversos tratadistas e professores, dentre os quais Bartel compila as passagens onde Susenbrotus, ${ }^{20}$ Burmeister, Nucius, Thuringus, Kircher, Bernhard, Janovka, Walter e Sheibe definem e exemplificam a figura da síncope. ${ }^{21}$
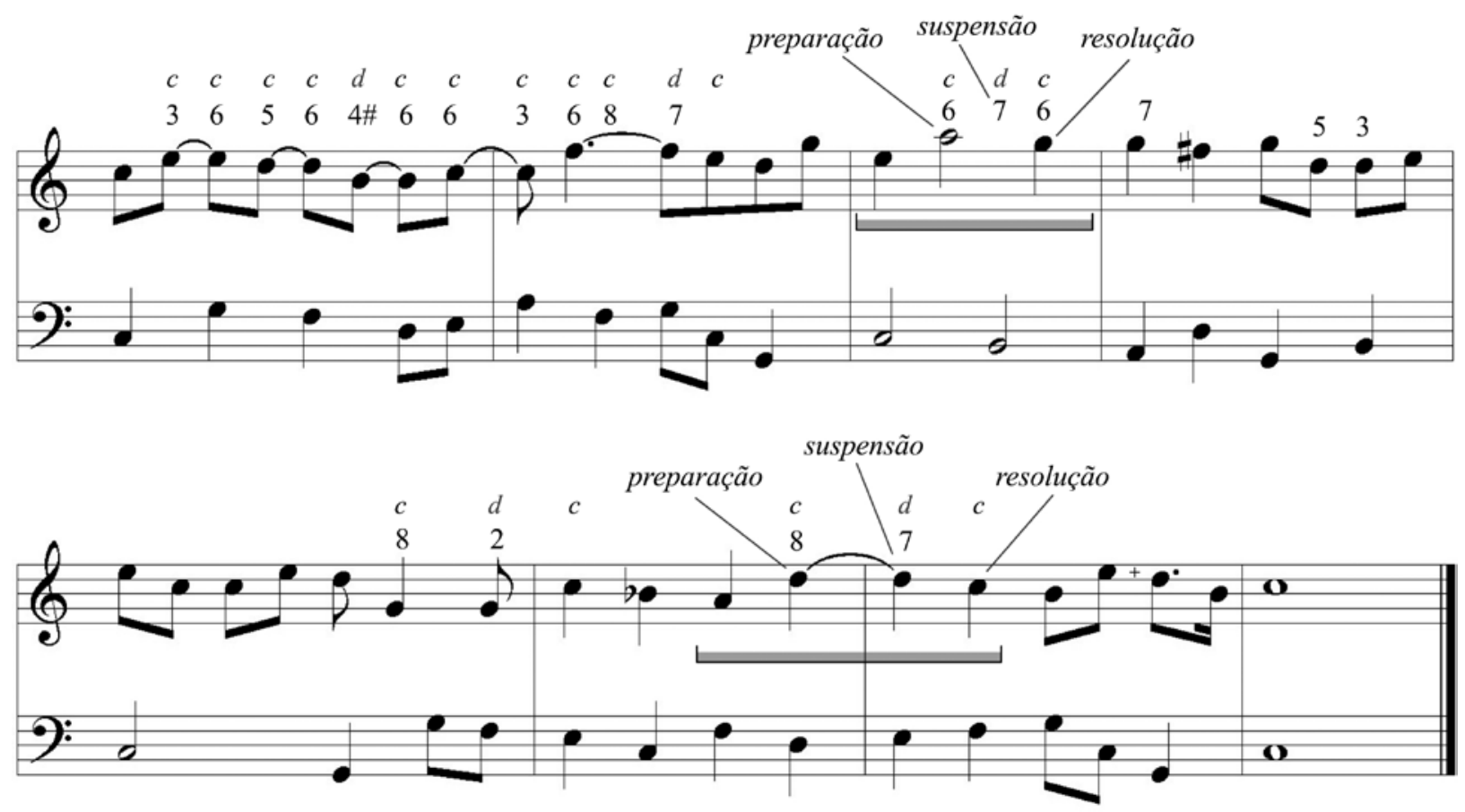

Ex.9 - Demonstrações de síncopes modernas conforme Rameau em $1722 .{ }^{17}$ 
Esse percurso de mais de três séculos - que separa (e une) as cláusulas sincopadas de Tinctoris, as cadeias de suspensões de Fux e as sincopações normalizadas por teóricos da harmonia moderna e pelos cultores da retórica musical - dá pistas das transformações que a síncope sofre no âmbito da própria música e teoria culta europeia. Esse tipo de processo de re-funcionalização, diluição ou deslocamento (onde um dispositivo anteriormente reservado para um determinado papel se vê expandido para papéis diferentes), ora desqualificando e ora qualificando, também se faz notar na formação disso que agora chamamos de música popular urbana. Música onde a transformação modernizadora, afirmadora, re-significadora ou trans-cultural surge em meio a percursos assim, de inflação, e não propriamente, ou exclusivamente, da invenção de algo que jamais se fez antes. ${ }^{22}$

Tal processo de adesão excessiva a um determinado dispositivo pode carregar o valor negativo de maneirismo (afetação, excesso, banalização, etc.). Estigma que contribui na desvalorização de uma artesanalidade que pode, por isso, ser vista como um stilus luxurians demais, um estilo imoderado, misturado, popularesco, de mau gosto, desinteligente, indiscreto, pobre e inculto justamente porque deseja imitar o culto (o rico, o inteligente, o original, etc.), e tal imitação se mostra, ou é percebida como, ilegítima, exagerada e indecorosa. ${ }^{23}$

\section{4 - Retransformação: da síncope moderna para a síncope do estilo livre}

Toda essa polifonia - as músicas e teorias que perpassam os séculos XV ao XVIII - assiste o surgimento de uma síncope sincrética, um dispositivo novo (moderno) que se consolidou no estoque das dissonância da tonalidade harmônica (notas de passagem, bordaduras, cambiatas, escapadas, apojaturas, antecipações, etc.). Uma síncope expandida que, em boa parte da narrativa contemporânea (séculos XIX e XX) da história da música universal (i.e., da música culta da Europa na Europa e nas suas colônias), vai se fazer representar por aquilo que a síncope (ligadura, retardo ou suspensão) se tornou na emblemática música de J. S. Bach.
0 que deu cunho específico à música do Barroco foi a experiência conjunta de toda a Europa que teve [...] na obra de Bach seu ponto culminante. 'E como toda a música alemã posterior remonta a Bach, o gênio musical alemão, dominaria de futuro no mundo ocidental' [...]. A obra de Bach é simultaneamente ponto de confluência e ponto de partida. Ponto de confluência da música europeia e ponto de partida da música futura das nações. (NEUNZIG, 1985, p.9). ${ }^{24}$

Barroca, clássica e romântica, a síncope dessa universal "música futura das nações" se faz representar minimamente nos fragmentos reunidos nos Ex.11 e 12. Nesses fragmentos as três etapas da antiga síncope - preparação, ligadura e resolução - vão sofrendo inflações de todo tipo: mutações, implantes, variações, ornamentações e combinações com outras diferentes espécies de dissonâncias. A rítmica da síncope é usada em texturas homorítmicas sugerindo o caminho para a sincopação das figuras de acompanhamento (Ex.11a). Entre a dissonância e sua resolução surgem permeios bastante sofisticados (Ex.11b). Cadeias de síncopes agora já ocupam papéis motívicos temáticos (Ex.11c). E certos mestres nos surpreendem com resoluções ascendentes (Ex.11d).

No correr dos séculos XVIII e XIX a teoria se vê obrigada a distinguir coisas que estão se tornando independentes na síncope: de um lado o deslocamento métrico e de outro as espécies de dissonâncias. A dissonância ocupa a preparação (Ex.12a). 0 desenho rítmico agora pode estar carregando dissonância de antecipação (Ex.12b) e não mais exclusivamente de suspensão ou retardo. Surgem novos usos para a síncope da antiga prática (Ex.12c). As suspensões não são explicitamente resolvidas (Ex.12d). Agora, rompendo a sisudez do estilo estrito, já estamos ouvindo o galante estilo livre. $\mathrm{E}_{\text {, }}$ como dizia o teórico musical alemão Heinrich Christoph Koch (1749-1816) em 1782: "no estilo livre, dissonância não precisa ser preparada" (KOCH apud RATNER, 1980, p.23). Agora, contando com esse "poderoso recurso para a produção de tensão expressiva, personificando em si o princípio estético essencial da tensão e relaxamento" (BENJAMIN, 1986, p.69), a musica burguesa europeia, caucasóide e culta, alcança a textura legítima e recorrente da sincopação plena (Ex.12e).

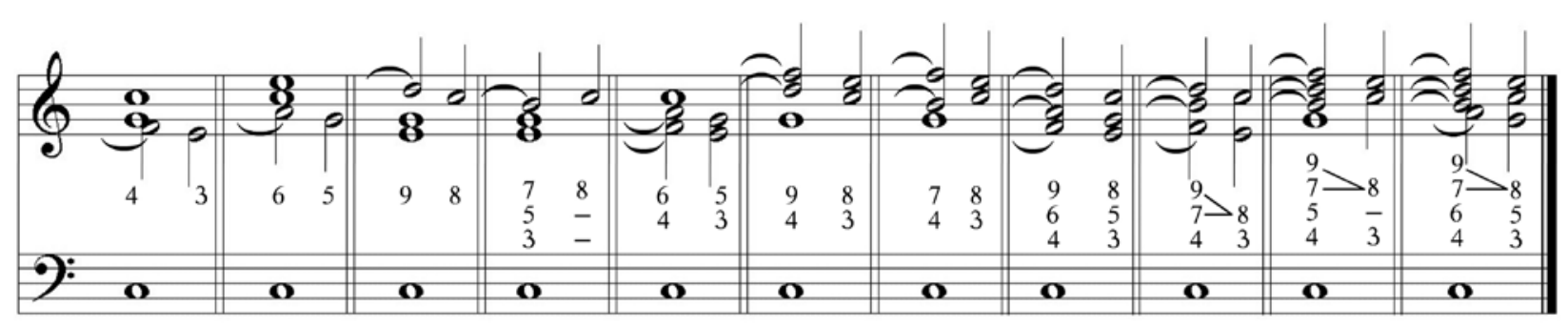

Ex.10 - 0 acorde perfeito maior e suas suspensões dissonantes segundo Kirnberger em 1773. ${ }^{18}$ 
a) Johann Gottfried Walter (1684-1748), Musicalisches Lexicon, 1732.

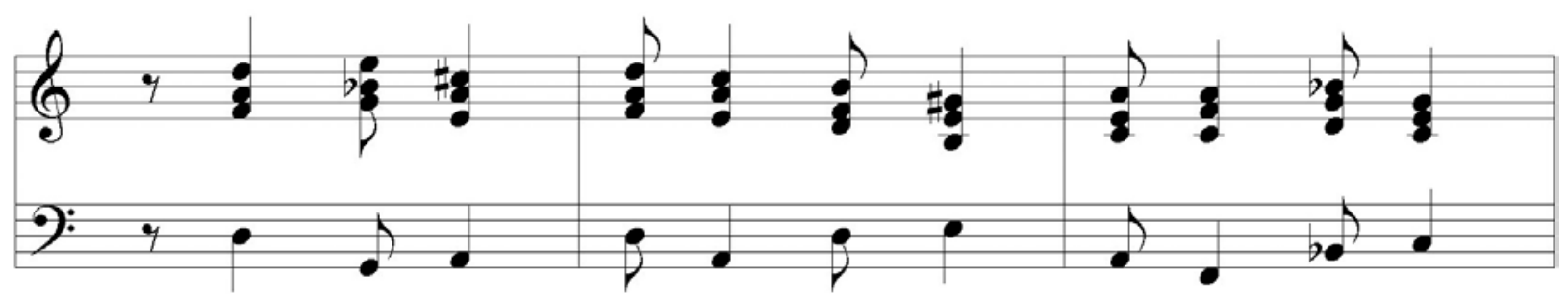

b) Johann Sebastian Bach (1685-1750), Concerto Italiano

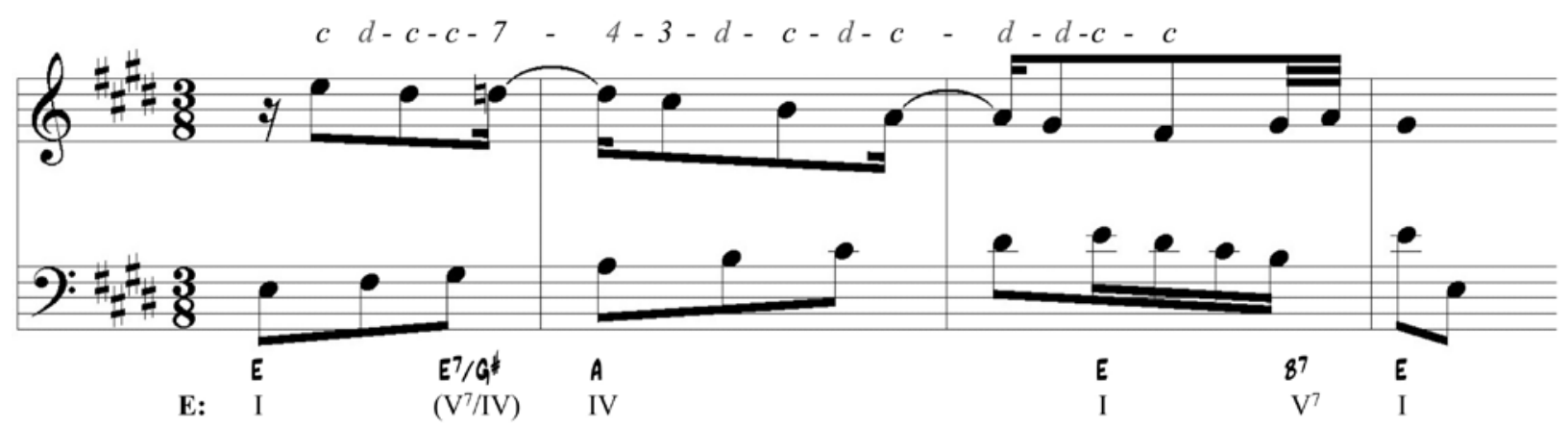

c) Johann Sebastian Bach, Inventio 6 (BWV 777)

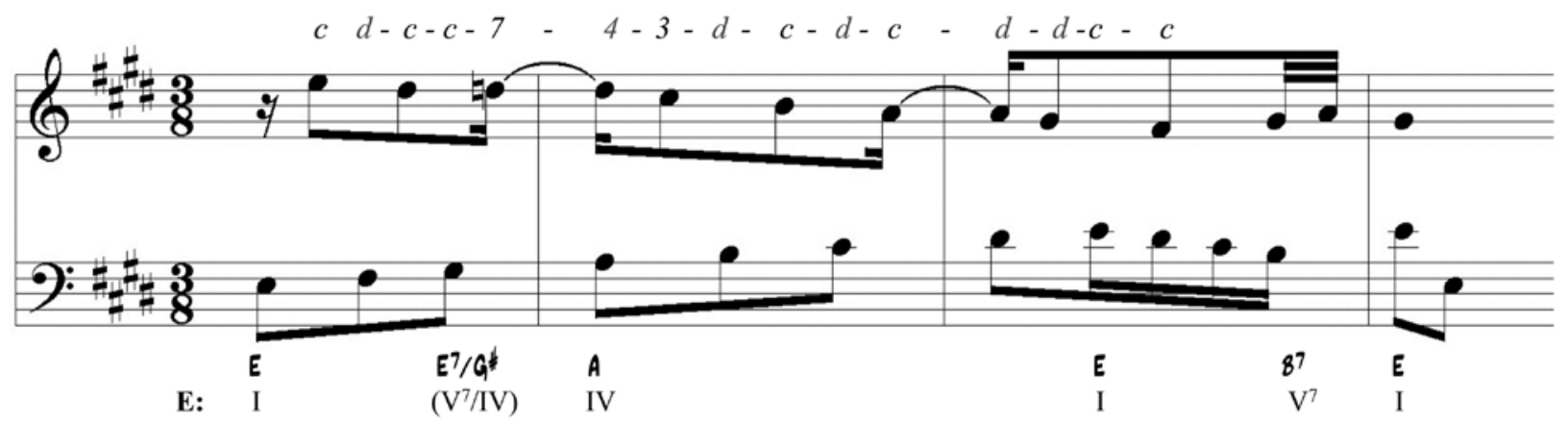

d) Johann Sebastian Bach, um caso de resolução ascendente

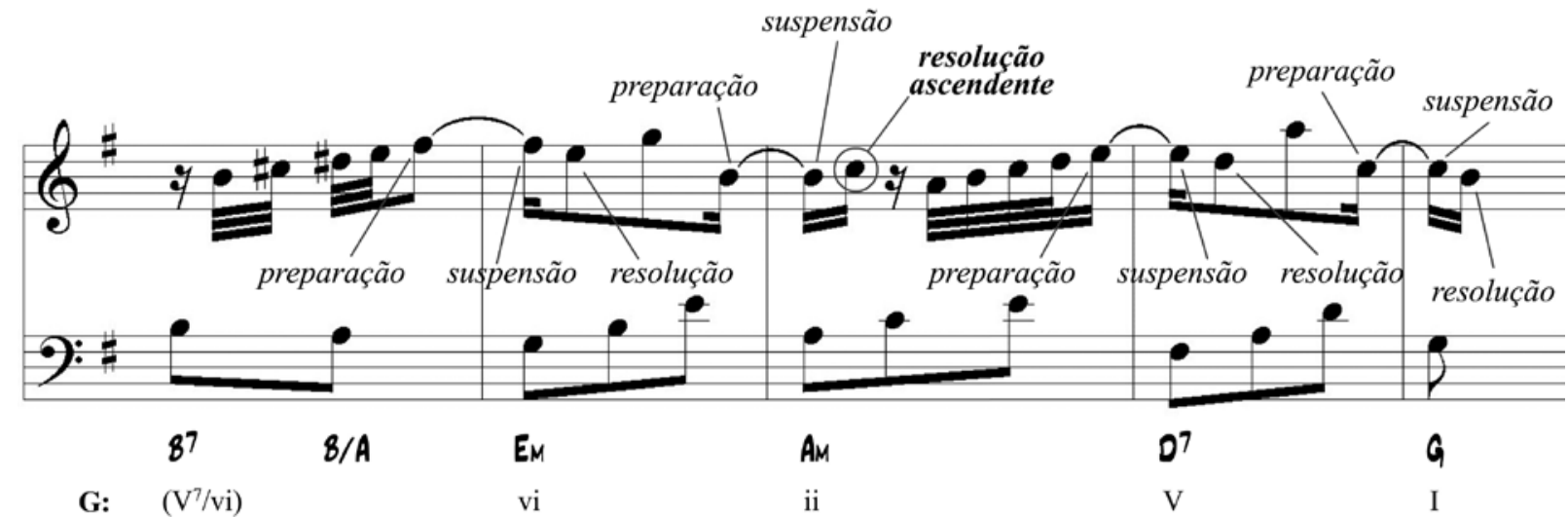

Ex.11 - Mostruário de síncopes europeias emblemáticas da música culta moderna. ${ }^{25}$ 
Com esses poucos fragmentos vamos percebendo que, com acentos vários, a figura de síncope é uma filha natural dessa "música das nações", dessa babel pós-bachiana, desta hegemônica tonalidade harmônica que nos cerca. Vamos apreendendo que o "conflito com a métrica prevalecente" (SALZER e SHACHTER, 1999, p.67) e o atrito com a consonância predominante que se dão numa síncope não são defeitos (arritmia, deformidade, imperfeição, fraqueza moral, funcionamento irregular ou falho, carência de linhagem, ou coisas do tipo). E que, embora seja uma tarefa um tanto dispendiosa, é possível notar que os traços de síncope estão mesmo certificados em tanta arte e registrados em tanta teoria.

\section{5 - Valoração: algumas síncopes são mais do que outras}

Um registro da síncope feito pelas elites letradas no Brasil nos inícios do século XIX foi deixado pelo mestre capela da Sé de São Paulo, o tenente coronel André da Silva Gomes (1752-1844). No seu tratado A arte explicada de contraponto, SILVA GOMES cuida da Ligadura nas lições 9a a 13a (LANDI, 2006, p.184-200). 0 zeloso espaço reservado ao assunto evidencia que, mesmo aqui - num Brasil dos idos anos de 1800 quando uma música popular vem se formando ao redor das igrejas, das corporações militares e das aglomerações urbanas - o efeito retórico expressivo da síncope é algo de grande valor a ser aprendido com cuidado e diligência pelo músico que está sofrendo a sua devida catequese ocidentalizante.

Conhecedor dos segredos da arte que explica, Silva Gomes sabe dos efeitos da síncope. Sabe que se trata de um contrário ao que é o regular, sabe do seu real deslocamento. Mas sabe também que esses efeitos não são impróprios, antes são valores artísticos altamente positivos na arte católica, conservadora e ocidental. Como todo músico minimamente treinado nos cânones da arte europeia, sabe que não se trata de tomar um único partido: tempo e contra-tempo, acordo e tensão, não são valores excludentes, são forças constituintes da música que interagem numa negociada síntese de opostos. "Essa ação e reação que da luta recíproca de forças discordantes extrai a harmonia do universo" (BURKE apud TOCH, 2001, p.146).

Ao final da 9a lição, Silva Gomes faz um precioso comentário, "Preceitos concernentes aos Usos e Modos de Formar a Ligadura", que antecede as lições específicas sobre a Ligadura:

Tendo estabelecido os Sábios a variedade de Espécies com que se propuseram a organizar o corpo da Composição, admitidas e ordenadas as Agradáveis Consonâncias e aspirando a tornar aprazivel o som das mesmas Dissonantes fazendo que elas fossem indices sensiveis da bela Harmonia, querendo, parece de propósito, chocar primeiro o ouvido com a Dissonância, para que depois ficasse mais susceptivel e recebesse com maior recreio a Consonância que se seguisse; nestes termos, proporcionando os Meios para que isso se conseguisse, eles estabeleceram experimentados preceitos entre os quais um deles muito especial e capaz de modificar a dura aspereza da Dissonância foi o uso e modo de unir estas Espécies com Ligaduras, chegando por esta descoberta a ponto de introduzir felizmente e com estimável apreço, as Falsas e Dissonantes nas Composições, prescrevendo as partes que a Ligadura se deve dividir, não menos do que muitas inerentes circunstâncias, todas importantes e precisas para o feliz êxito de uma bem ajustada Composição (SILVA GOMES in LANDI, 2006, p.184).

Assim, Silva Gomes re-ensina a grande regra: tratar da síncope é tratar da variedade como valor estético, pois "In omni contrapuncto varietas accuratissime exquienda est" - "a variedade é exigência urgentíssima em todo contraponto" (TINCTORIS apud FORNER e WILBRANDT, 1993, p.25). Conforme o musicólogo alemão Heinrich Besseler (1900-1960), no século XV

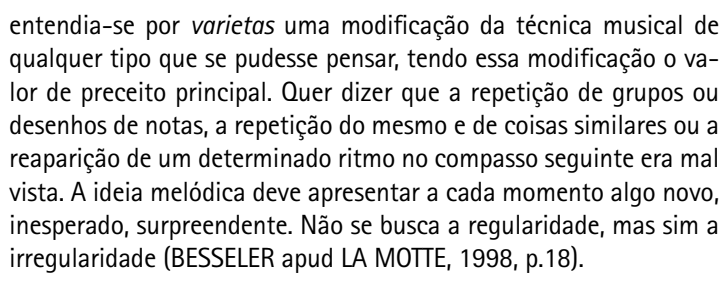

entendia-se por varietas uma modificação da técnica musical de qualquer tipo que se pudesse pensar, tendo essa modificação o valor de preceito principal. Quer dizer que a repetição de grupos ou desenhos de notas, a repetição do mesmo e de coisas similares ou a reaparição de um determinado ritmo no compasso seguinte era mal vista. A ideia melódica deve apresentar a cada momento algo novo, inesperado, surpreendente. Não se busca a regularidade, mas sim a irregularidade (BESSELER apud LA MOTTE, 1998, p.18).

Como os demais tratadistas, Silva Gomes distingue duas qualidades principais de ligadura: A ligadura precisa (a síncope necessária, i.e., a dissonante) "refere-se ao tratamento da suspensão, onde a nota ligada deve ser preparada e seguida de sua resolução, ordinariamente, por grau conjunto descendente" (LANDI, 2006, p.41). A ligadura voluntária "refere-se ao tratamento da síncope, pela qual ocorre apenas um jogo alternante de consonâncias podendo a nota ligada ser tratada livremente, isto é, alcançada e/ou deixada por grau conjunto ou salto" (idem).

Como o Ex.3 já pré-anunciou, tal distinção específica é técnica, mas é também uma distinção de valor: agrega capital artístico, social, cultural, simbólico, linguístico, escolar. Consolidada no ambiente sacro erudito pré-moderno, tal distinção técnico-valorativa sofreu seus sincretismos e numa espécie de repercussão impremeditada se fez qualidade de grande apreço nos mundos contemporâneos das músicas populares sincopadas. A distinção se fundamenta na concepção artística de que, embora não seja possível nem desejável desenvolver tramas musicais só com a ligadura precisa (a síncope dissonante), seu uso implica habilidade, beleza, esmero e maestria, implica em agudeza e engenho.

Não se trata, é claro, de excluir totalmente o uso da ligadura voluntária (a síncope consonante). Trata-se de colocá-la em seu devido lugar e proporção. Entre as duas se estabelece uma relação intencionalmente assimétrica: uma variedade equilibrada por uma desigualdade. 0 conhecedor do ofício, o "gênio", se faz reconhecer pelo uso da síncope mais difícil, expressiva, complexa, variada, inteligente e criativa, ou seja: a síncope de tipo dissonante e/ou ornamentada. De maneira relativa, geral, e combinada com uma série de fatores diversos (musicais e extra-musicais), vamos notar que estilos, gêneros, músicas e músicos que invertem tal assimetria - i.e., usam mais ou usam demais as síncopes consonantes - são julgados como algo de qualidade menos artística, mais pobre, inferior, monótona, vulgar ou menor. 
a) Wolfgang Amadeus Mozart (1756-1791), fragmento do Quarteto, K. 387, Molto Allegro, 1782.

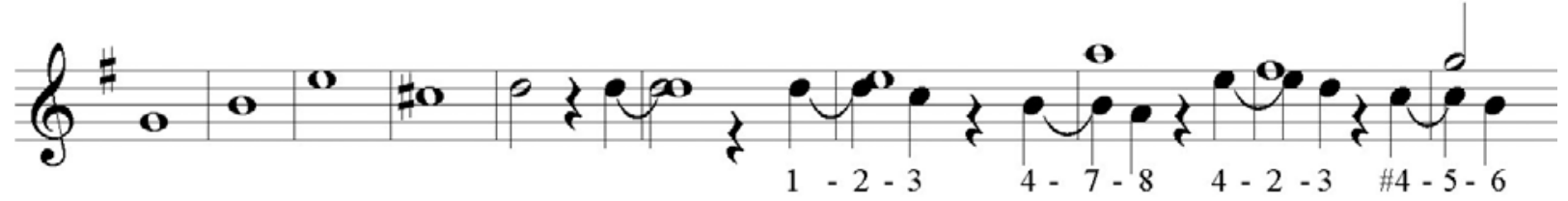

b) Carl Philipp Emanuel Bach (1714-1788), Kurze und leichte Klavierstucke, n. 12.
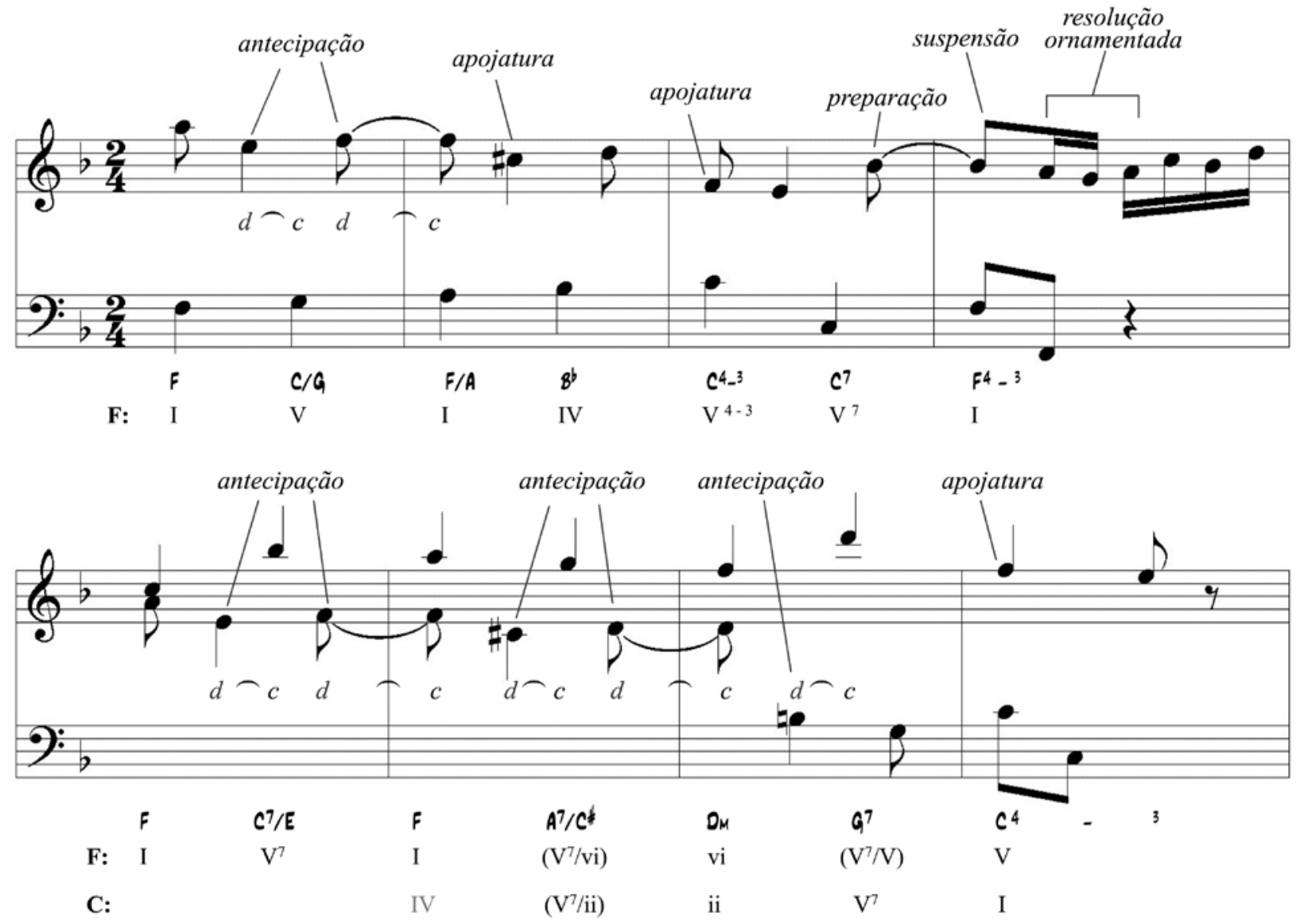

c) Franz Joseph Haydn (1732-1809), Sonata n. 12.

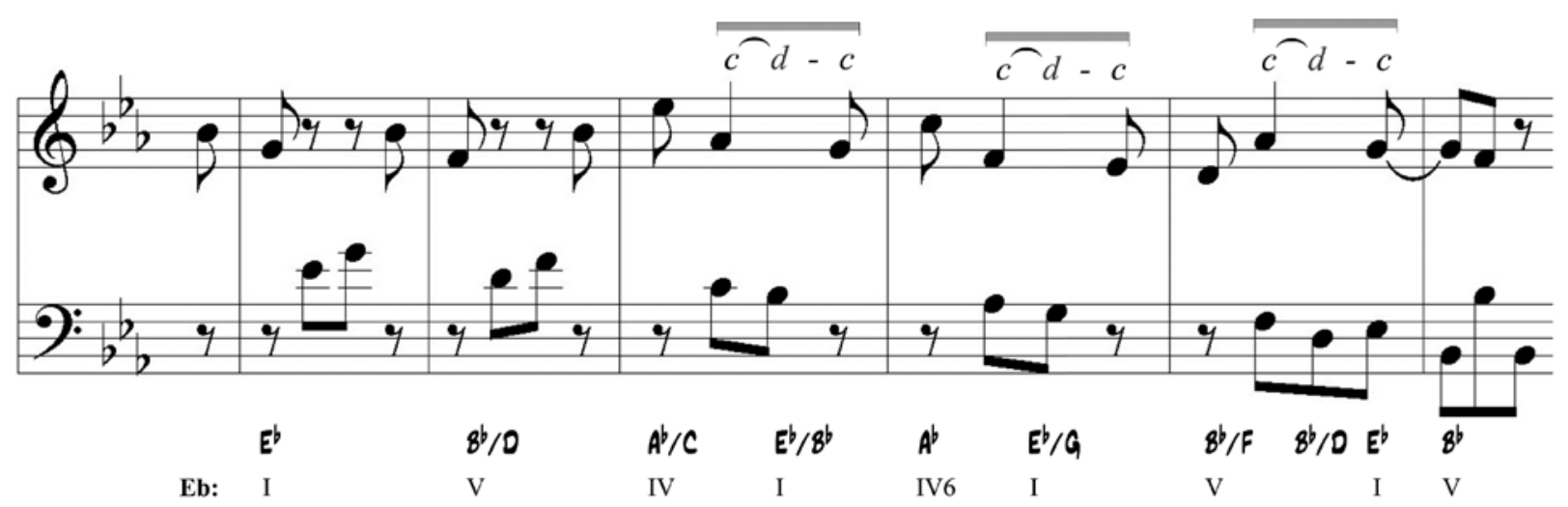

Ex. 12 - Mostruário de síncopes europeias emblemáticas da música culta moderno-contemporânea. ${ }^{26}$ 
d) Ludwig van Beethoven (1770-1827), Sonata, op.1, (Pathétique), Rondo, 1798-99.
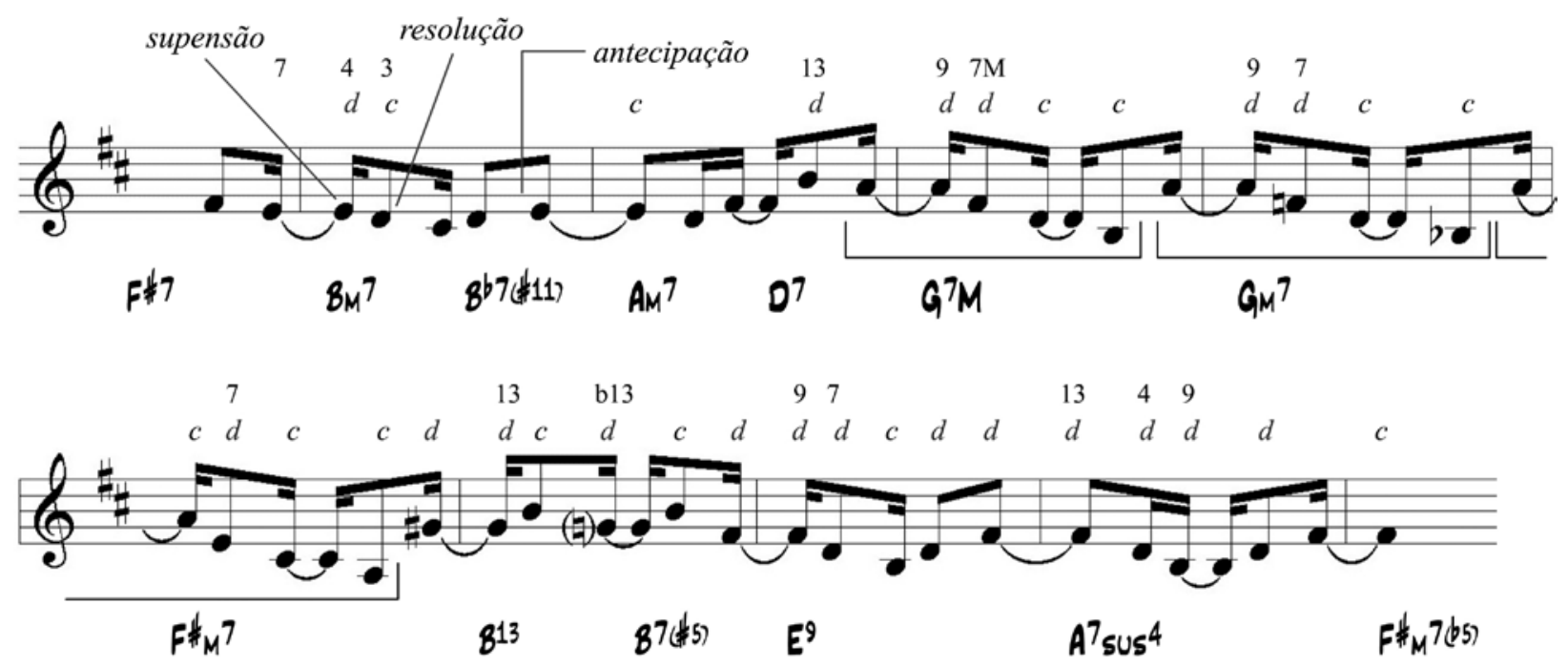

e) Robert Schumann (1810-1856), Kinderscenen, op. 15, n. 10 (Fast zu ernst), 1838.

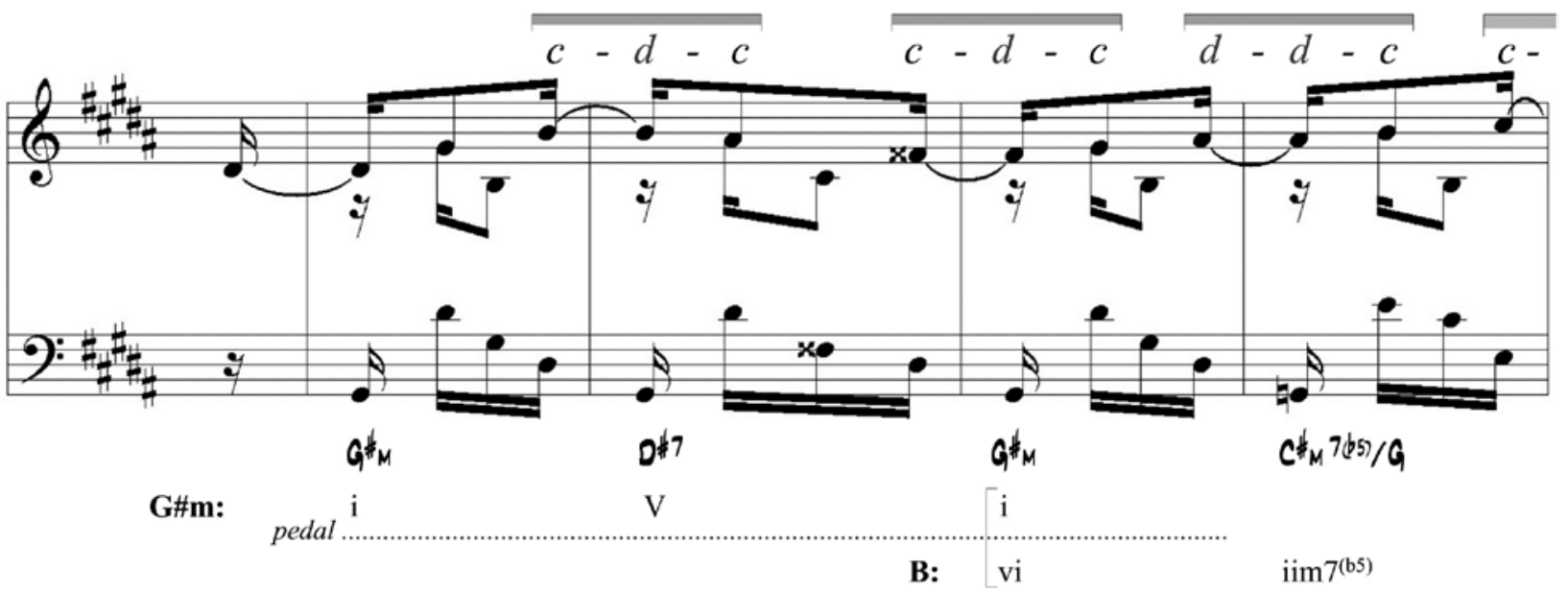

(Cont.) Ex. 12 - Mostruário de síncopes europeias emblemáticas da música culta moderno-contemporânea. ${ }^{26}$

\section{6 - Síncopes características: os garfinhos na música popular brasileira}

Não raro tal distinção - que, vale insistir, não é autosuficiente, pois é apenas uma das tantas especificidades que atuam nos domínios de um campo - realça matizes xenofóbicas e nacionalistas: a "melhor sincope" (a "boa", a "característica") é a "mais brasileira" (ou, para outras pessoas, em outros lugares, será a "melhor" ou a "mais" caribenha, cubana, negra, portenha, jazzista, etc.). 0 critério está sutilmente presente na distinção entre o que é música sincopada mais ou menos "comercial" (síncopes difíceis vendem menos, são menos dançáveis, e são percebidas como tristes, problemáticas, etc.) e entre o que é mais ou menos "tradicional" (síncopes difíceis são mais legitimas, antigas, originais, verdadeiras, de raiz, etc.). Não formalmente expressa - e sempre entre aspas, pois tudo isso tem validade delimitada -, tal distinção atua no nivel do conhecimento tácito, subentendida, é uma espécie de segredo recôndito que contribui para alimentar a crença estereotipada de que "algumas síncopes são superiores" e por isso devem ser "separadas e conservadas" como cultura autêntica e pura. Com isso, dentro deste campo da música popular, algumas músicas, seus músicos e simpatizantes, podem perfeitamente não reconhecer ou validar esse tipo de critério, enquanto que outros vão se identificar totalmente com ele.

0 Ex.13 reúne algumas sincopes brasileiras intencionalmente escolhidas em obras emblemáticas produzidas por mestres da "nossa" artesanalidade sincopada recente. Antes, uma observação deve ser feita. Esses fragmentos são grafados aqui de maneira simplificada, sugestiva e 
provisória e visam ilustrar o argumento (de que as combinações das qualidades das alturas nos desenhos rítmicos das síncopes influem numa distinção valorativa). Como se sabe, nas músicas populares uma composição não se fixa com demasiada rigidez, já que na escrita, leitura, interpretação, arranjo ou improvisação que se pratica nesse campo tudo isso (notas, tessituras, divisões rítmicas, articulações, quantidades e qualidades dos acordes, tonalidades, instrumentação, andamentos, etc.) vai mesmo se modificando a cada singular recriação. Certamente tais impermanências implicam em medidas analíticas objetivas (quais intervalos são consonantes ou dissonantes, quais figurações são sincopes ou não, etc.) que vão diferir substancialmente das medidas aferidas aqui.

A intenção do Ex.13 é estimular associações entre, por um lado, o que conhecemos destas obras e autores, o lugar e o valor que estes "nomes" - o "feitiço do nome do mestre" como dizia Walter Benjamin (apud BOURDIEU, 2007, p.287) -, ocupam na música, na cultura, na economia, no mundo social em que vivemos. $E$, por outro lado, a ocorrência objetiva de letras " $d$ " (dissonâncias) contrapostas às letras "c" (consonâncias). Importa notar a relação de proporção/desproporção entre " $d$ " e c", a variedade (riqueza, complexidade, originalidade) das combinações sequenciadas e a qualidade das posições ocupadas. Por ex., "d" em preparações ou resoluções pode ser sinal de engenho, criatividade, modernização, virtuosismo, impureza, etc.; "c" em lugar de suspensão pode ser sinal de imperícia, menor qualidade artística, humor, ironia, etc. Importa notar que o valor tradicional (tonal, ocidental) não está na opção por "d" ou por "c", e sim no equilibrio ou desequilibrio conseguido entre elas. Combinações " $d$ " e "c" também dão indícios do desenvolvimento causa-efeito da trama. Por ex., estereotipadamente, "c" pode indicar repouso ou distensão, enquanto que " $\mathrm{d}$ " implica em tensão e movimento, etc.

Contudo, é preciso frisar com clareza que tais associações ou referências não são suficientemente alimentadas exclusivamente pelo puro isolamento técnico-objetivo das combinações entre " $d$ " e "c". Como se sabe, o valor em música popular é uma grandeza relacional, depende de efeitos combinados onde aspectos incontáveis e diversos interagem. Assim, os parâmetros de ritmo e altura jamais estão sozinhos na tarefa de julgar qual é ou não a boa síncope. 0 ritual leva em conta quem está fazendo música para quem, aonde e por que, o texto das canções, as qualidades da harmonia, o timbre, a tessitura, o vibrato, o andamento, a instrumentação, o volume, os processamentos de mixagem, a mise-en-scène, a expressão corporal, a iluminação, os olhares, todo o ambiente que um fato musical evoca incluindo o tamanho, o comportamento e a adesão de algum público aficionado, etc. Enviesadamente os fragmentos amostrados no Ex. 13 realçam tão somente os aspectos do controle das alturas que compõem a melodia (intervalos consonantes ou dissonantes, notas do acorde ou notas auxiliares, tensões disponiveis, preparação, suspensão, resolução, etc.), mas o horizonte de compreensão da questão das síncopes características (brasileiras ou outras) é, como se sabe, bem mais amplo e miscigenado. A síncope é também (ou muito mais) uma questão de elocução, um modo de expressar, assim, não é propriamente uma questão exclusiva da composição (notação, etc.), é um componente de interpretação e performance, um tipo de pronúncia ou sotaque que atua também (ou muito mais) no tecido rítmico dos "acompanhamentos" destas melodias.

\section{7- Em conclusão}

A visita a esta memória da síncope oportuniza notar que, na arte e na teoria, a síncope não é uma noção unívoca que se acha homogeneamente pré-estabelecida e paralisada em algum lugar. Como tantos dispositivos musicais que vão atravessando o processo da colonização ocidental, a síncope da tradição erudita não é um patrimônio privativo e anistórico que, puro, ileso e autônomo, vai percorrendo épocas e lugares sem sofrer redefinições e experimentar novos usos e pronunciações. Arguta, prestigiosa, institucional, dominadora e milenar, essa síncope letrada toma parte das "mestiçagens que nos constituem" (BARBERO, 2008, p.262), é uma das muitas "falas" - das muitas maneiras de pensar, de ver, ouvir, fazer e julgar - que discursam nas longas e tortuosas conversas que estão na linha do telefone-sem-fio das transformações do mundo.

Mesmo correndo o risco de reelaborar o que já está dito em alguns dos "múltiplos discursos sobre música popular", vale concluir notando que observações desta natureza - a busca de uma historicidade formativa do que seria a síncope brasileira, a busca do que e em que medida compõe uma espécie de DNA, ou de "alma" da musicalidade brasileira, etc. - dependem do cruzamento de um espesso caldo de considerações. E nesta densa trama de "impossivel pureza" (BARBER0, 2008, p.263), de inúmeras e inacabadas interações transformativas, as qualidades e posicionamentos das alturas no interior do desenho rítmico da síncope são apenas mais alguns dos mínimos detalhes, frações pequeninas de artesanalidade sutil e subliminar, que se misturam nos nossos julgamentos de valor. 
a) Ernesto Nazareth (1863-1934), Brejeiro, maxixe.

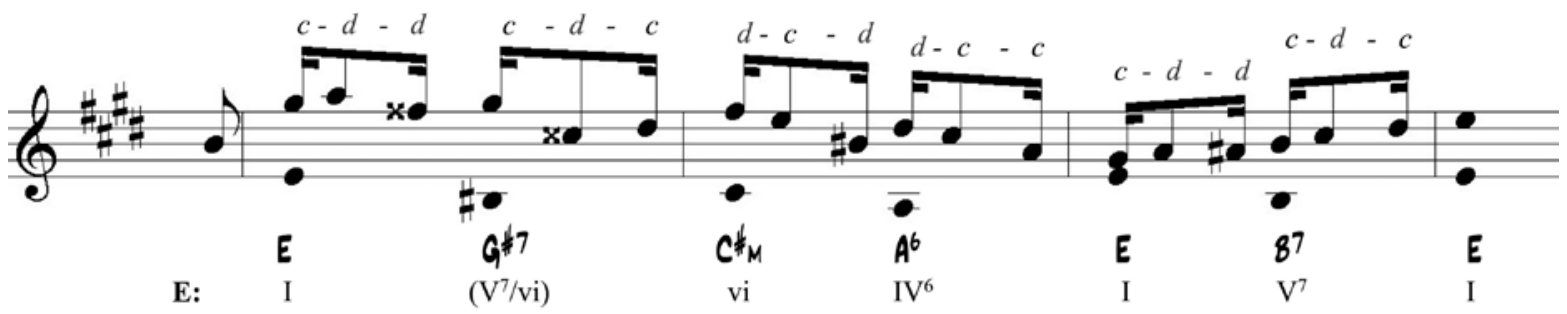

b) Pixinguinha (1897-1973), Carinhoso, choro-canção.
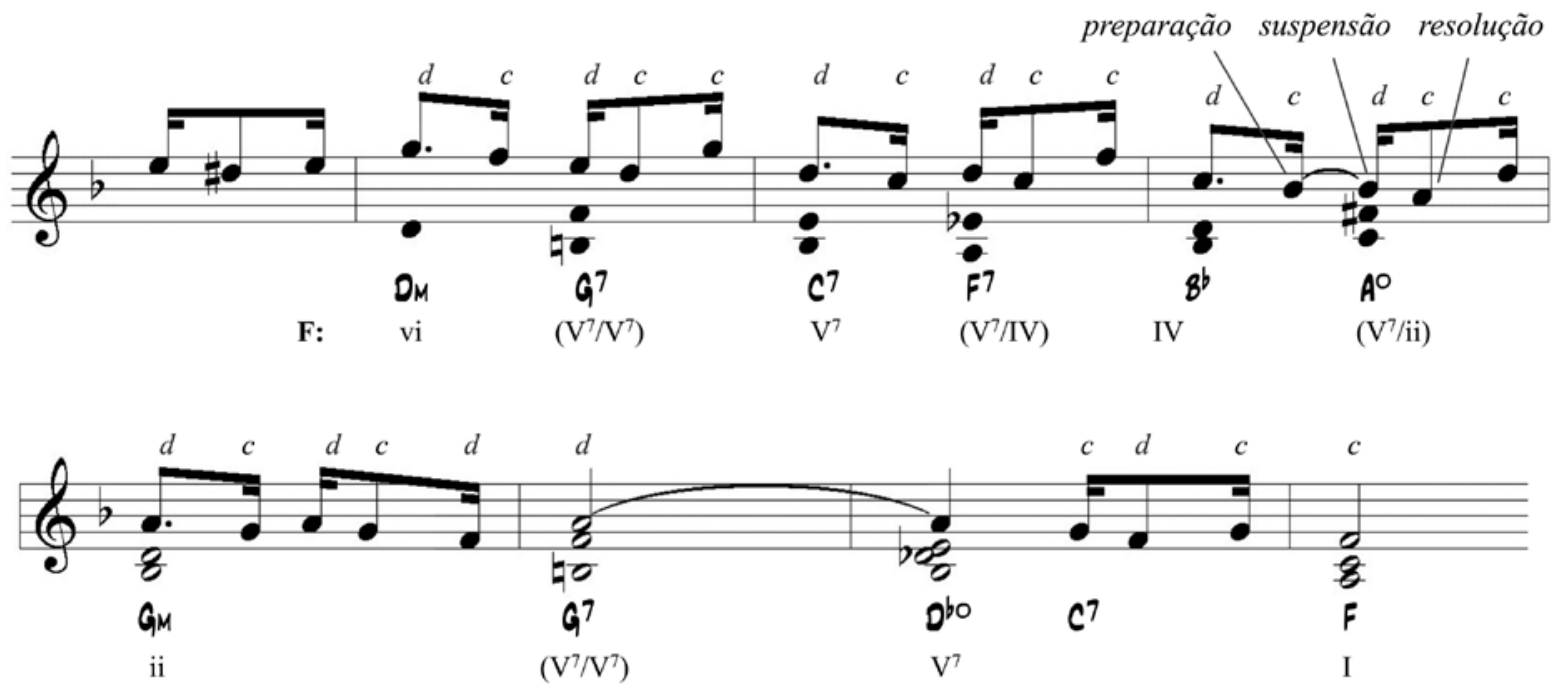

c) Pixinguinha, Lamentos, choro.
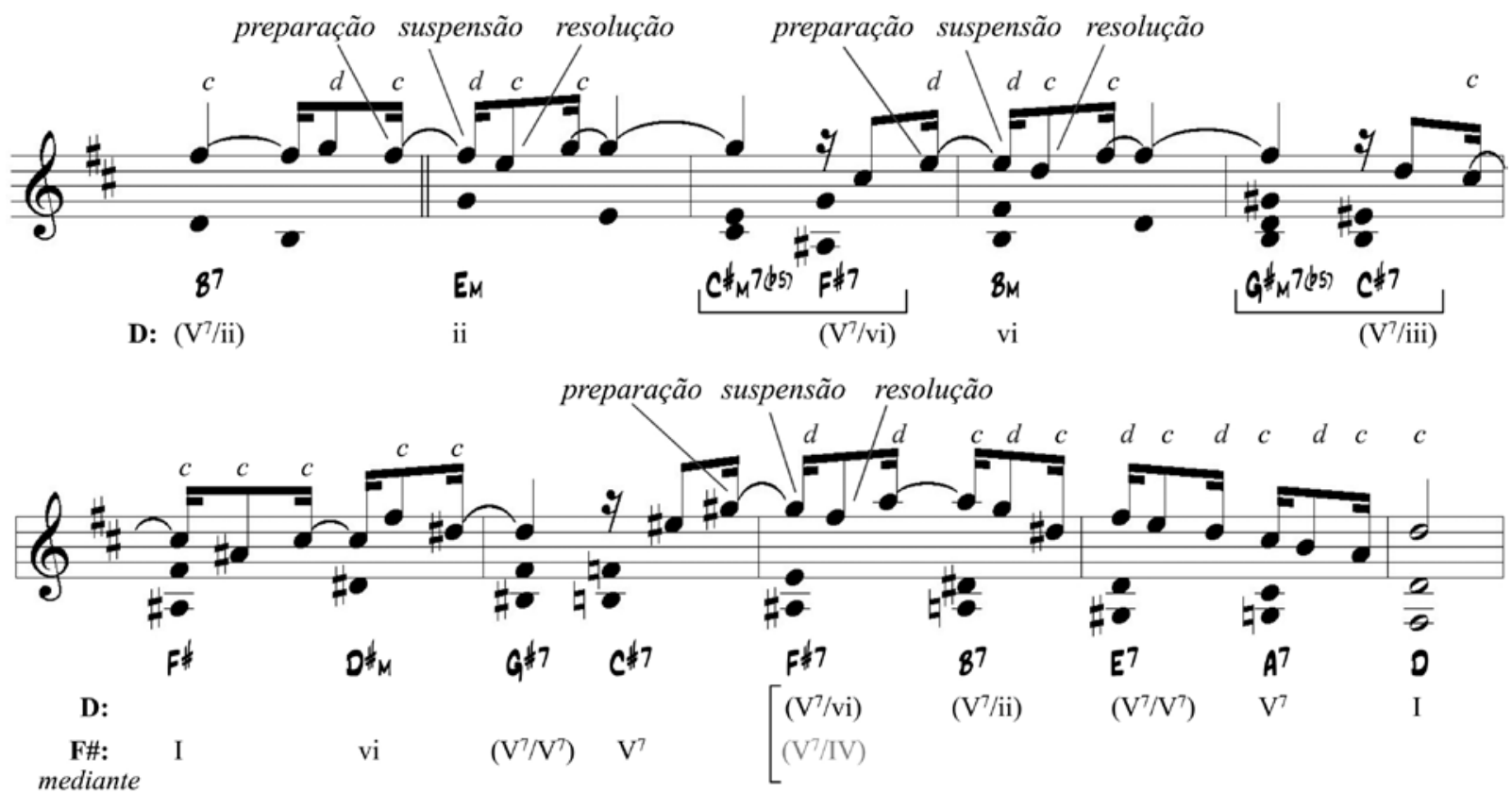

Ex.13 - Mostruário mínimo do valor da síncope em desenhos melódicos da MPB. ${ }^{31}$ 
d) Tom Jobim (1927-1993), Chega de Saudade.
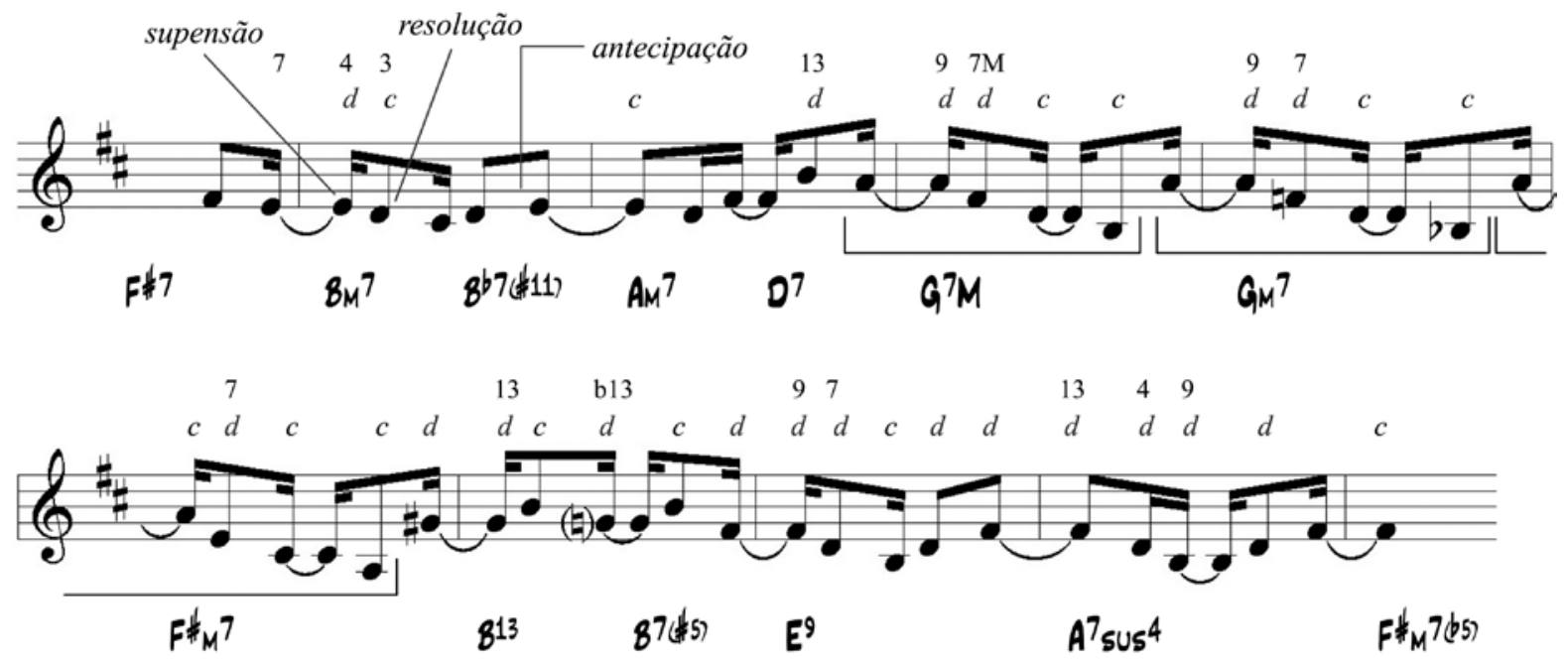

e) Hermeto Pascoal (1936-), Surpresa.
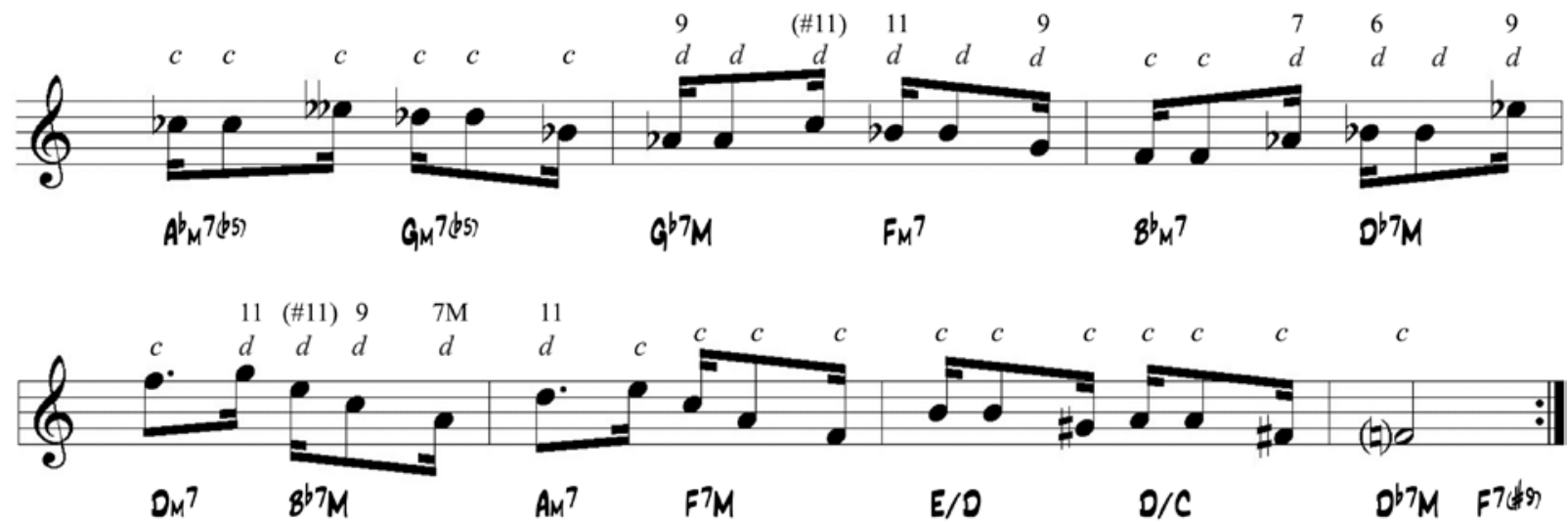

(Cont.) Ex.13 - Mostruário mínimo do valor da síncope em desenhos melódicos da MPB. 
f) Edu Lobo (1943-) e Vinícius de Moraes (1913-1980), Só me fez bem.
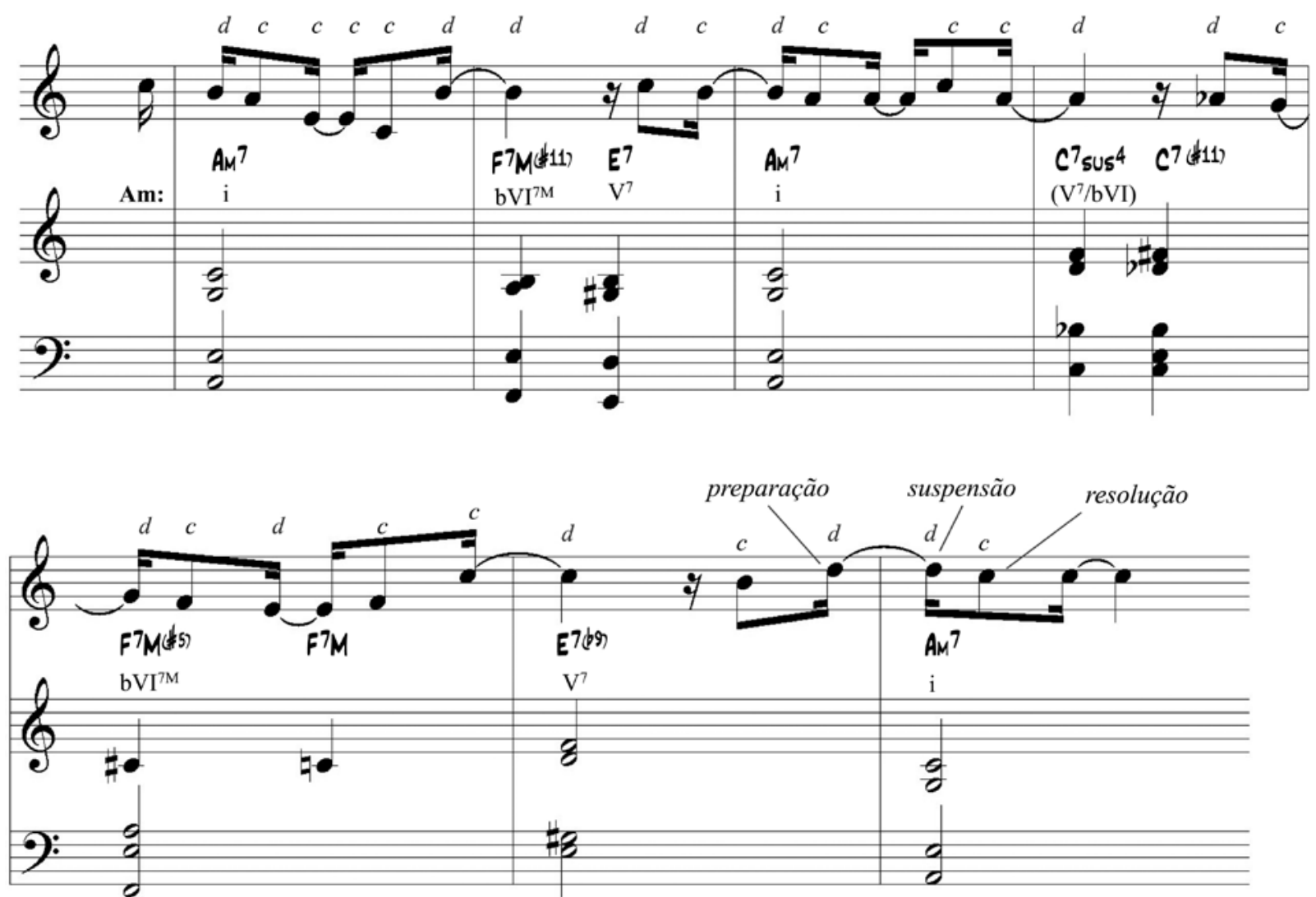

g) Gilberto Gil (1942-) e Capinam (1941-), Soy loco por ti América.

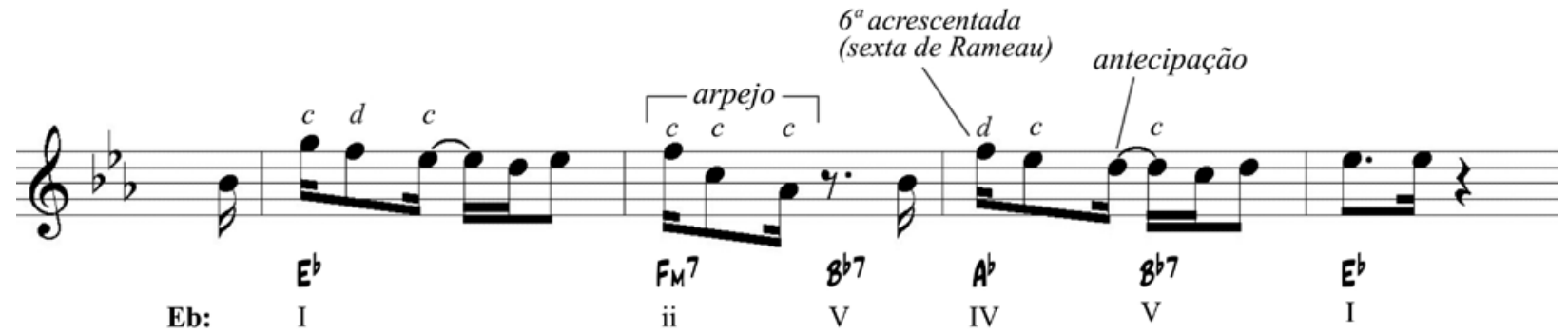

(Cont.) Ex.13 - Mostruário mínimo do valor da síncope em desenhos melódicos da MPB. 


\section{Referências}

ABBAGNANO, Nicola. Dicionário de filosofia. São Paulo: Mestre Jou, 1982.

ABDOUNUR, Oscar João. Matemática e música. São Paulo: Escrituras, 1999.

ADORNO, Theodor. Filosofia da nova música. São Paulo: Perspectiva, 2004.

ANDRADE, Mário de. Dicionário musical brasileiro. Belo Horizonte: Itatiaia, 1989.

ANDRADE, Mário de. Ensaio sobre a música brasileira. 4a ed. Belo Horizonte: Itatiaia, 2006.

ARISTÓTELES. Retórica. Portugal: Imprensa Nacional, Casa da Moeda, 1998.

BARBERO, Jesús Martin. Dos meios às mediações. Rio de Janeiro: Editora UFRJ, 2008.

BARTEL, Dietrich. Musica Poetica: musical-rhetorical figures em german baroque music. Lincoln: University of Nebraska Press, 1997.

BENÉVOLO, Caio. A polêmica Forkel-Rousseau. Debates - Cadernos do Programa de Pós-Graduação em Música do Centro de Letras e Artes da UNIRIO, Rio de Janeiro, CLA/UNIRIO, n. 7, p.57-97, 2004.

BENJAMIN, Thomas. Counterpoint in the style of J. S. Bach. New York: Schirmer Books, 1986.

BENJAMIN, Thomas. The craft of modal counterpoint: a practical approach. New York: Schirmer Books, 1979.

BERRY, Wallace. Metric and rhythmic articulation in music. Music Theory Spectrum, v. 7, Time and Rhythm in Music, Spring, 1985. p.7-33.

BESSA, Virgínia de Almeida. "Um bocadinho de cada coisa": trajetória e obra de Pixinguinha. Faculdade de Filosofia, Letras e Ciências Humanas da USP, 2005. (Dissertação de Mestrado em História).

BLUTEAU, Raphael. Vocabulario portuguez e latin. Coimbra, 1712 - 1728. Disponivel em: <http://www.ieb.usp.br/online/>. Acesso em: 01 ago. 2008.

BOURDIEU, Pierre. O poder simbólico. Rio de Janeiro: Bertrand Brasil, 2007.

BRENET, Michel. Diccionario de la música. Barcelona: Editorial Ibéria, 1962.

CANÇADO, Tânia Mara Lopes. 0 "fator atrasado" na música brasileira: evolução, características e interpretação. Per Musi. Belo Horizonte, v.2, 2000. p.5-14.

CARVALHO, Any Raquel. Contraponto modal. Porto Alegre: Editora Sagra Luzzatto; Novak Multimedia, 2000.

CAVALCANTI, Alberto Roseiro. Música popular: janela espelho entre o Brasil e o mundo. Programa de Pós- Graduação em Sociologia da Universidade de Brasília, UNB, 2007. (Tese de Doutorado).

COOPER, Grosvenor e MEYER, Leonard B. Estructura ritmica de la música. Barcelona: Idea Books, 2000.

DAHLHAUS, Carl. La idea de la música absoluta. Barcelona: Idea Books, 1999.

DAHLHAUS, Carl. Studies in the origin of harmonic tonality. Oxford: Princeton University Press, 1990.

DEBUSSY, Claude. Monsieur Croche e outros ensaios sobre música. Rio de Janeiro: Nova Fronteira, 1989.

DESCARTES, René. Compendio de música. Madrid: Editorial Tecnos, 1992.

FAGERLANDE, Marcelo. 0 Baixo Contínuo no Brasil: a contribuição dos tratados em língua portuguesa. Rio de Janeiro:

Universidade Federal do Estado do Rio de Janeiro - UNIRIO, 2002. (Tese de Doutorado em Música).

FORNER, Johannes; WILBRANDT, Jurgen. Contrapunto creativo. Barcelona: Labor, 1993.

FORTE, Allen e GILBERT, Steven E. Introducción al análisis Schenkeriano. Barcelona: Idea Books, 2003.

FUX, Johann Joseph. The study of counterpoint. New York: Norton, 1971.

GAINES, James R. Uma noite no palácio da razão. Rio de Janeiro: Record, 2007.

GARCÍA CANCLINI, Néstor. Culturas hibridas: estratégias para entrar e sair da modernidade. 4. ed. São Paulo: Edusp, 2003. GROUT, Donald J. e PALISCA, Claude V. História da música ocidental. Lisboa: Gradiva, 1994.

HARNONCOURT, Nikolaus. O diálogo musical: Monteverdi, Bach e Mozart. Rio de Janeiro: Jorge Zahar Ed., 1993.

HOUAISS. Dicionário eletrônico Houaiss da língua portuguesa. Versão 1.0: Editora Objetiva, 2001. CD-ROM.

HUANG, Cheng Zhi Anna e CHEW, Elaine. Palestrina Pal: a grammar checker for music compositions in the style of Palestrina. In: CONFERENCE UNDERSTANDING AND CREATING MUSIC - UCM, 5 ${ }^{\text {th }}, 2005$ Caserta, Anais... Caserta, 2005. Não paginado.

IKEDA, Alberto T. Escolas de samba ou de marcha? O Estado de São Paulo. São Paulo, ano 7, n. 500, 24 fev. 1990.

JEPPESEN, Knud. Counterpoint: the polyphonic vocal style of the sixteenth century. New York: Dover, 1992.

JEPPESEN, Knud. The style of Palestrina and the dissonance. Mineola, New York: Dover Publications, 2005.

KENNAN, Kent W. Counterpoint: based on eighteenth-century practice. Englewood Cliffs: Prentice-Hall, 1987.

KIRNBERGER Johann Philipp. The true principles for the practice of harmony. Journal of Music Theory, Autumn, 1979. v. 23 , n. 2, p.163-225

KOMAR, Arthur J. Theory of suspensions: a study of metrical pitch relations in tonal music. Princeton, New Jersey: Princeton University Press, 1971.

KRAMER, Jonathan D. Studies of time and music: A Bibliography. Music Theory Spectrum, v. 7, Time and Rhythm in Music, p.72-106. Spring, 1985. 
LA MOTTE, Diether de. Contrapunto. Barcelona: Idea Books, 1998.

LA RUE, Jan. Analisis del estilo musical. Barcelona: Labor, 1989.

LANDI, Marcio Spartaco. Lições de contraponto segundo a arte explicada de André da S. Gomes. Fortaleza: Expressão Gráfica e Editora Ltda, 2006.

LESTER, Joel. Rameau and eighteenth-century harmonic theory. In: CHRISTENSEN, Thomas (Ed.). The Cambridge History of Western Music Theory. Cambridge: Cambridge University Press, 2006. p.753-777.

LIMA REZENDE, Gabriel S. S. Música, experiência e memória: o desenvolvimento da partitura e as margens do processo Revista Resgate n. 18, p.83-98, 2009.

LÓPEZ CANO, Rubén. Música y retórica en el Barroco. México: UNAM. 2000.

LUCAS, Mônica. Aspectos decorosos e cômicos em minuetos de Haydn. Musica Hodie, Goiânia, Volume III, n. 1/2, 2003, p.105-16.

LUCAS, Mônica. Uma visão retórica da agudeza no Quarteto de Cordas 0p.33, N.5 de Franz Joseph Haydn. Per Musi, Belo Horizonte, n.16, 2007. p.21-32

MACHADO, Cacá. O enigma do homem célebre: ambição e vocação de Ernesto Nazareth. São Paulo: Instituto Moreira Salles, 2007.

NAPOLITANO, Marcos. A síncope das ideias: a questão da tradição na música popular brasileira. São Paulo: Fundação Perseu Abramo, 2007. (Coleção História do Povo Brasileiro).

NEUNZIG, Hans A. Uma nova música europeia. Bonn: Inter Nationes, 1985.

NEVES, Paulo. Mixagem: o ouvido musical do Brasil. São Paulo: Editora Max Limonad, 1985.

ORTIZ, Renato (org.). Pierre Bourdieu: Sociologia. São Paulo: Editora Ática, 1983.

OWEN, Harold. Modal and tonal counterpoint: from Josquin to Stravinsky. New York: Schirmer Books, 1992.

PALISCA, Claude V. (Ed.). Norton anthology of western music: ancient to baroque. New York: Norton, 1996.

PISTON, Walter. Contrapunto. Cooper City: SpanPress, 1998.

POUND, Ezra. ABC da literatura. São Paulo: Cultrix, 1986.

PRANDINI, José Carlos. Um estudo da improvisação na música de Hermeto Pascoal: transcrições e análises de solos improvisados. Instituto de Artes, Unicamp, 1996. (Dissertação de Mestrado).

RAMEAU, Jean-Philippe. Treatise on harmony. New York: Dover Publications, 1971.

RAMEAU, Jean-Philippe: Traite de L'harmonie réduite ci son principe naturel. París: Klincksieck. 1986.

RATNER, Leonard G. Classic music: expression form, and style. New York: Schirmer Books, 1980.

RIEMANN, Hugo. History of music theory. Lincoln: University of Nebraska Press, 1962.

ROUSSEAU, Jean-Jacques. Diccionario de música. Madrid: Ediciones Akal, 2007.

SAFATLE, Vladimir. Muito longe, muito perto: dialética, ironia e cinismo a partir da leitura hegeliana de 0 sobrinho de Rameau. Artefilosofia, Ouro Preto, Instituto de Filosofia, Artes e Cultura da Universidade Federal de Ouro Preto, n. 2, p.36-55, jan. 2007.

SALZER, Felix; SHACHTER, Carl. El contrapunto en la composición. Barcelona: Idea Books, 1999.

SANDRONI, Carlos. Feitiço Decente:transformações do samba no Rio de Janeiro (1917-1933). Rio de Janeiro: Jorge Zahar Ed.; UFRJ, 2001.

SCHENKER, Heinrich. Counterpoint (1). New York: Schirmer Books, 1987.

SCHOENBERG, Arnold. Exercícios preliminares em contraponto. São Paulo: Via Lettera, 2001a.

SCHOENBERG, Arnold. Harmonia. São Paulo: Editora da Unesp, 2001 b.

SHUKER, Roy. Vocabulário de música pop. São Paulo: Hedra, 1999.

SODRÉ, Muniz. Samba, o dono do corpo. Rio de Janeiro: Codecri, 1979.

TATARKIEWICZ, Wladyslaw. Historia de la estética. Volume 3 (1400-1700). Madrid: Akal, 1991.

TOCH, Ernst. Elementos constitutivos de la música. Barcelona: Idea Books, 2001.

TOMÁS, Lia. Ouvir o logos: música e filosofia. São Paulo, Editora UNESP, 2002.

TOMLINSON, Gary (Ed.). The Renaissance. In: STRUNK, W. Oliver e TREITLER, Leo (Ed.). Source Readings in Music History. New York: Norton, 1998. p.281-508.

TORRINHA, Francisco. Dicionário Latino Português. Porto: Gráficos Reunidos, 1942.

TRAVASSOS, Elizabeth. Modernismo e música brasileira. Rio de Janeiro: Jorge Zahar, 2000.

TRAVASSOS, Elizabeth. Pontos de escuta da música popular no Brasil. In: ULHÔA, Martha; OCHOA, Ana Maria (Org.). Música popular na América Latina: pontos de escuta. Porto Alegre: Editora da UFRGS, 2005, p.94-111.

VALLE, Ione Ribeiro. Pierre Bourdieu: a pesquisa e o pesquisador. In: BIANCHETI, Lucídio e MEKSENAS, Paulo (Orgs.). A trama do conhecimento: teoria, método e escrita em ciência e pesquisa. Campinas: Papirus, 2008. p.95-117.

WASON, Robert W. Musica practica: music theory as pedagogy. In: CHRISTENSEN, Thomas (Ed.). The Cambridge History of Western Music Theory. Cambridge: Cambridge University Press, 2006. p.46-77. 
WEBER, Max. Os fundamentos racionais e sociológicos da música. São Paulo: Edusp, 1995.

WEBERN, Anton. 0 caminho para a música nova. São Paulo: Novas Metas, 1984.

WISNIK, José Miguel. Machado maxixe: o caso Pestana. Teresa Revista de Literatura Brasileira, São Paulo, FFLCH/USP, n. 4/5, p.13-79, 2003.

\section{Notas}

1 A expressão "da diferença do que ensinam os antigos e os modernos" foi tomada de LANDI (2006, p.122).

2 Considerando que "a música popular atrai os eruditos" e "pesquisadores vinculados às universidades", TRAVASSOS (2005) mapeia a produção acadêmica que trata da música popular nos campos da etnomusicologia, antropologia, estudos literários, semiótica da canção, sociologia e historiografias. Para SANDRONI, que tratando da "síncope brasileira" relê diversos estudiosos (tais como Edison Carneiro, Mario de Andrade, Andrade Muricy, Oneyda Alvarenga, Nogueira França, etc.), "de fato, alguns musicólogos viram na síncope uma característica definidora não apenas do samba, mas da música popular brasileira em geral" (SANDRONI, 2001, p.19). Sobre a síncope como um tema privilegiado nos estudos da música brasileira ver ANDRADE (1989; 2006), CANÇADO (2000), MACHADO (2007), NAPOLITANO (2007), SANDRONI (2001), SODRÉ (1979) e WISNIK (2003).

3 A expressão "um bocadinho de cada coisa" foi tomada de BESSA (2005).

4 Sobre as normas de adequação música e texto (Latim) na polifonia ver Benjamin (1979, p.9-10), Carvalho (2000, p.105-107), Forner e Wilbrandt (1993, p.103-105), Jeppesen (2005, p.38-47) e La Motte (1998, p.174-181).Tratando da "inclusão do ritmo" no estilo palestriano Forner e Wilbrandt (1993, p.96-103) sugerem a unidade de tempo de 70 pulsações por minuto, nesse andamento a figura de síncope ocupa duas unidades de tempo. 0 andamento é um fator a ser considerado na re-significação da síncope. Para uma comparação acentuada com um caso atual de "síncope brasileira" onde a figura de sincope ocupa uma unidade de tempo, temos que, "enquanto no Rio [de Janeiro] a pulsação média dos sambas[-de-enredo], nos desfiles [de carnaval], tem sido de 132 a 138 [pulsações por minuto], ela é de 138 a 144 em São Paulo, pela marcação de 1989" (IKEDA, 1990). Assim, no andamento, é vertiginosa a diferença que se observa entre uma suposta síncope sincope palestriniana

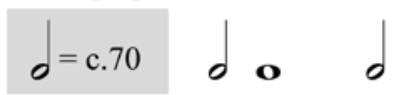

sincope de samba-de-enredo

\section{c. 140} palestriniana e uma estereotipada sincope de samba-de-enredo.

50 uso do termo massivo em contexto anterior aos meios de comunicação de massa foi sugerido por GARCÍA CANCLINI (2003, p.255-256): "A rigor o processo de homogeneização das culturas autóctones da América começou muito antes do rádio e da televisão, nas operações etnocidas da conquista e da colonização, na cristianização violenta de grupos com religiões diversas, - durante a formação dos estados nacionais - na escolarização monolíngue e na organização colonial ou moderna do espaço urbano. [...] A noção de cultura massiva surge quando as sociedades já estavam massificadas".

6 Uma alusão ao título de NEVES (1985). 0 próprio termo "católico" - do Latim catholice (universalmente), catholicus (universal, geral, regular), catholicum (regra geral), catholica (propriedades gerais, o universo), (TORRINHA, 1942, p.130) - é útil para pensarmos a memória da síncope. No cadinho que nos coube nesse Novo Mundo, aprendemos a falar da "síncope brasileira" (ou, conforme o narrador, da "síncope cubana", da "sincope jamaicana", da "síncope do Ragtime norte-americano", etc.) da mesma maneira que aprendemos a falar de um catolicismo "brasileiro". Um sutil contra-senso, já que o termo "católico" pretendeu dizer justamente aquilo "que é universal". Mas esse contra-senso (esse universal vertido em particular) deslocou-se frente ao fato de que, apesar das origens (já sincréticas) do termo e da própria religião, o Brasil, como outras paragens do Novo Mundo, acabou negociando seu jeito particular de ser "católico". E esse "jeito de ser", esse "modo próprio de perceber e narrar, contar e dar conta" (BARBERO, 2008, p.261) acaba sendo reconhecido como tal.

7 A expressão "muito longe, muito perto" foi tomada de SAFATLE (2007).

8 Datado de 1477 o Liber de arte... de Johannes Tinctoris (c.1435-1511) é um marco renascentista do registro teórico da síncope. Tal registro foi precedido - informa RIEMANN (1962, p.249-250) - por normalizações da síncope encontradas em tratados franceses cem anos mais antigos. Tratados como o célebre Ars nova (c.1322), o Ars perfecta in musica e o Liber musicalium atribuídos a Philippe de Vitry (1291-1361), e também em trabalhos atribuidos a Johannes de Muris (c.1290-c.1351) como o Libellus cantus mensurabilis (c.1340). No repertório as dissonâncias sincopadas também estão presentes nessa música do século XIV, p.ex., em obras de Philippe de Vitry, Guillaume de Machaut (c.1300-1377) e Francesco Landini (c.13271397). Cf. GROUT e PALISCA (1994) e PALISCA (1996). Observa-se com essas tão antigas figuras novas que, desde cedo, no "canto polifônico racional", a síncope é um pormenor sui generis dentre os "meios técnicos de expressão" que, "com a finalidade de moldar a paixão", decorrem daquilo que o sociólogo alemão Max Weber (1864-1920) chamou de "notação racional" (cf. LIMA REZENDE, 2009). Por volta de 1911, em seu "fundamentos racionais e sociológicos da música", WEBER (1995) destacou correlações entre a "notação" e o "papel fundamental que a lgreja desempenhou em todo o processo de racionalização" que culminou na moderna música ocidental - a música "condicionada" pela "Akkordhamonik" (harmonia de acordes). E que isto tenha sido possivel teve seu fundamento [...] nas soluções precedentes de problemas tecnicamente racionais. Assim particularmente na criação da notação racional (sem a qual nenhuma composição moderna seria sequer concebivel) e, já antes, na criação de instrumentos determinados que impeliam à interpretação harmônica dos intervalos musicais, e sobretudo na criação do canto polifônico racional. Teve papel nessas realizações na Alta idade Média o monacato dos territórios missionários do Norte-0cidente, que sem suspeitar o alcance posterior de seus atos racionalizou para seus fins a polifonia popular [...]. Foram particularidades absolutamente concretas - condicionadas sociologicamente e pela história da religião - da situação externa e interna da igreja cristã no Ocidente que originaram ali, a partir de um racionalismo próprio apenas ao monacato do Ocidente, esta problemática musical, que na sua essência era de tipo "técnico" (WEBER, 1995, p.50-51).

9 Adaptado de LA MOTTE (1998, p.76). No exemplo a letra " $c$ " corresponde a um intervalo consonante e a letra " $d$ " a um dissonante. Por conseguinte, suspensões como ${ }^{-9} 9-8,-2-1,-4-5,-7-8$, bem como as eventuais resoluções ascendentes (que aparecem mais tarde na música culta europeia), não estariam ainda em uso na época de Josquin (LA MOTTE, 1998, p.77). Note-se ainda que o desenho de síncope não é puramente melódico, já que depende de no mínimo duas vozes.

10 Conforme LA MOTTE (1998, p.78-81). Para estimular comparação com uma grafia da síncope que aparece na música popular atual, as cláusulas dos Ex. $2 a$ e $2 b$ foram reescritas (no destaque) em compasso dois por quatro.

110 Ex.3 procura resumir diversas referências. Em um primeiro grupo - reunindo autores que seguem a normalização proposta por Fux, onde a síncope ocupa a destacada posição de quarta espécie de contraponto - estão: CARVALHO (2000), FORNER e WILBRANDT (1993), FORTE e GILBERT (2003), FUX (1971), JEPPESEN (1992; 2005), KENNAN (1987), OWEN (1992), SALZER e SHACHTER (1999), SCHENKER (1987) e SCHOENBERG (2001a). Dentre os que não seguem as espécies fuxianas estão: BENJAMIN (1979), LA MOTTE (1998) e PISTON (1998). Os termos usados em tratados brasileiros e portugueses nos séculos XVIII e XIX foram recolhidos em FAGERLANDE (2002) e LANDI (2006). Para estudos que abordam as relações entre métrica e altura na tonalidade harmônica ver BERRY (1985), COOPER e MEYER (2000), KOMAR (1971), KRAMER (1985) e LA RUE (1989). 
12 Conforme BENJAMIN (1979, p.150 e 173). Esses fragmentos não trazem todas as informações que constam na partitura e os comentários analíticos são parciais.

130 uso da dissonância é assim um critério de valor altamente positivo no julgamento artístico ocidental. Seu emprego denota risco, virtuosismo, habilidade e maestria composicional. Com isso, Palestrina pôde ser considerado um dos grandes do seu tempo porque, entre outras coisas, conseguia usar mais dissonâncias do que outros maestros da época. No ranking demonstrando estatisticamente a capacidade de uso de diversas dissonâncias (notas de passagem, suspensões, bordaduras e antecipações) compilado por HUANG e CHEW (2005) com o auxilio de um software para análise musical, vemos que Palestrina aparece em primeiro lugar com 18,37\% de dissonâncias, em segundo vem Tomás Luis de Victoria (1548-1611) com 14,8\%, depois William Byrd (1540-1623) com 10,57\% e por fim Orlando di Lasso (c.1530-1594), com 7,84\%.

14 Não se trata, é claro, de uma não percepção do ideal de diversidade defendido pelos grandes teóricos do renascimento como Tinctoris e Zarlino. Fux conhece a importância artística da variedade, basta ir até à sua 5 a espécie, por isso mesmo chamada de "contraponto florido" (FUX, 1971, p.64-67). Mas é que o diligente Fux é um personagem do lluminismo exercendo o poder de abstração e o melhor da concepção pedagógica de seu tempo: "a maneira do lluminismo conhecer [e logo ensinar] uma coisa era: identificar, separar e classificá-la" (GAINES, 2007, p.190). Fux trata do uso da sincope em cláusulas (cadências) em diversas passagens ao longo do Gradus... , p.ex., no "Exercitii V. Lectio III. De trium partium Fugis".

15 Ver ainda Livro 2 (da natureza e propriedade dos acordes) Artigo 1 e Artigo 4 (RAMEAU, 1986). Para Rameau o efeito de síncope é algo comparável a uma colisão, dai a origem do termo. Sincope seria composta por duas palavras gregas: syn e copto (RAMEAU, 1971, p.78; ROUSSEAU, 2007, p.368). Syn é um prepositivo que implica em juntamente (ao mesmo tempo, associação, etc.) que aparece em palavras como sincronia, sinergia, sinfonia, sinônimo, sintese, simetria, simbiose, símbolo, etc. Já copto (-cope) significa bater, colidir ou cortar e é usado como pospositivo no eruditismo latino do renascimento em palavras como apócope (mudança fonética que consiste na supressão de um ou vários fonemas no final de uma palavra, por exemplo: cine, por cinema, bel por belo), perícope (trecho da Biblia ou de um livro) e síncope (HOUAISS).

160 texto "Syncope, en Musique" de Rousseau foi publicado primeiramente em 1765, no XV volume (p.747) da célebre Encyclopédie... editada por Diderot e D'Alembert entre 1751 e 1772.

17 A partir de RAMEAU $(1986$, p.298; 1971, p.316).

18 A partir de KIRNBERGER (1979, p.172).

19 Adotando o termo "suspensão", BARTEL (1997, p.396) não deixa de avisar que, em inglês, suspention é normalmente usado como tradução de syncopatio ou syncopa. No entanto, suspention tem conotação de harmonic syncopation e, em inglês, este termo ficou mais reservado para os aspectos da síncope que implicam no controle das questões de altura. Por outro lado, o termo inglês syncopation é normalmente entendido como uma alteração de ordem rítmica (não necessariamente implicando em dissonâncias no campo das alturas). Tal separação se mostrou necessária na contemporaneidade, pois desde a síncope do estilo livre (ver itens 4 e 5), nem todas as dissonâncias acomodadas no desenho ritmico da síncope são suspensões (ou retardos). A advertência de Bartel - igualmente lembrada nas notas do tradutor in FORTE e GILBERT (2003, p.60) - é determinante para os estudos da síncope no Brasil referenciados em publicações de língua inglesa. Nos dicionários, enciclopédias ou outros textos em inglês, possivelmente, as informações sobre a síncope estarão compartimentadas. Em parte as informações estarão no verbete síncope, onde, no geral, a ênfase recairá nos aspectos de deslocamento métrico, pulso, ritmica, prosódia, etc. Mas serão os verbetes "suspensão" (Francês e inglês: suspension; Alemão: vorhalt; Italiano: sospensione; Espanhol: suspensión) e "retardation" (retardo) que, provavelmente, trarão informações sobre a questão das alturas da sincope tradicional (aquela que antecede o estilo livre). Na cultura viva das sincopes, parece inadequado, para dizer assim, especializar ou compartimentar de maneira muito rígida as diferentes propriedades que compõem o denso entendimento das dissonâncias acentuadas. Mas, dependendo de tendências e intenções, teóricos, críticos, professores, e artistas podem mesmo escolher o caminho da compartimentação paramétrica. E isso pode ser positivo ou não dependendo de inúmeras outras variáveis. Em qualquer caso o alerta de Bartel continua válido. Como leitores e/ou pesquisadores vamos exercer nossas escolhas informados e informando sobre os riscos e benefícios desta compartimentação especifica que carrega sequelas das estereotipadas compartimentações de fundo e mais gerais da nossa cultura atual (i.e. da musicologia de viés eurocêntrico ou anglo-americano) que prefere realmente distinguir suspensão de síncope. Suspensão implica no reino das alturas, termo mais reservado à síncope apolínea, a síncope caucasiana, pensante, letrada, europeia, ocidental, tradicional, histórica e de formação cristã, é a erudita síncope do Velho Mundo, etc. Sincope implica no reino das ritmicas (a sincopada, a sincopação), termo mais reservado à síncope dionisíaca, a síncope rebolada, negra, afro-miscigenada ou afro-latina, ocidentalizada, sincrética, oral, corporal e sem história - é a síncope de transe que encanta os corpos e as palmas das mãos que se confundem nesse nosso Novo Mundo, todo ele tão quente e sincopado, etc. E assim vamos reafirmando nossas crenças e preconceitos inabaláveis: a música que pensa não é sincopada e a música sincopada não pode pensar.

20 Em torno de 1540 o professor e humanista alemão Joannes Susenbrot (c.1484-1543) dizia que "a syncope ocorre quando uma letra ou silaba é removida do meio de uma palavra" (BARTEL, 1997, p.396). Acepção idêntica se encontra no Vocabulário Portuguez \& Latino de Raphael BLUTEAU, publicado entre 1712 e 1728 e tido como "o mais antigo dicionário da língua portuguesa". Segundo Bluteau a "Syncopa" é termo gramatical e ocorre "quando se tira uma letra, ou sílaba do meio de uma palavra, dizendo duum em lugar de duorum, composius em lugar de compositus". Já "Syncope" é termo médico, "deriva-se do grego Syncoptein, cortar, porque corta o coração, e todas as faculdades vitais [...]" (BLUTEAU, 1712-1728, p.818). Assim, instituída pelos eruditos da história literária, poética e linguística, essa noção de síncope interatua com a noção de síncope instituída para a observação da música. A síncope da gramática é um recurso culto aceito na avaliação dos desvios, transformações e reinvenções que ocorrem com as palavras em situações coloquiais e nas variações mais populares da cultura oral, como, por ex., nas célebres variações sincopadas que transformaram "vossa mercê" em "vossemecê" em "vosmecê" e chegaram até o "você", que por aférese (supressão de fonema no princípio da palavra) já se reinventou como "ocê" ou "cê" e, que por apócope (supressão no final da palavra), já tornou possivel até o uso escrito do solitário "c" como um pronome de tratamento. Tal maneira de entender o percurso das palavras em direção aos usos de caráter mais atual e popular (que notamos nos estudos dos colegas que se ocupam da síncope fonética), em alguma medida, parece influir naquelas soluções do campo acadêmico musical que, numa espécie de simplificação metodológica conveniente, pondo em plano bem mais secundário o aspecto das alturas, escolhe focar o aspecto rítmico da síncope como um parâmetro essencial na apreciação das músicas de registro hibrido, oral e popular. Músicas historicamente recentes (dos finais do século XIX para cá) que se desenvolveram no entorno dos centros urbanos do Novo Mundo passando por transformações análogas aos desvios que, por síncope, se dão na língua falada.

21 Conforme BARTEL (1997, p.402), alguns desses autores preocupam-se com a etimologia da palavra. Para o musico poeticus tcheco Tomáš Baltazar Janovka (1669-1741), syncopatio ou syncopsis, vem do grego Syncopo. Para o teórico e compositor alemão Johann Gottfried Walther (1684-1748) a palavra grega é synkopto. E, para ambos, o termo grego foi traduzido para o Latim como ferio (ferir, golpear, lograr, enganar) ou verbero (atacar, fustigar, deitar por terra, esmagar com palavras em um discurso). No Latim, conforme TORRINHA (1942, p.852), a palavra syncopa (ou syncope) significa desmaio; syncopo implica em cair com uma síncope; syncopatus: que tem uma síncope. A palavra suspensus pode significar algo preso em cima, algo que se sustém nos ares, que está na expectativa, na incerteza, incerto, que depende, submisso, parado, retido, etc. (TORRINHA, 1942, p.850).

$22 \mathrm{Em}$ certa medida, esse fenômeno de inflação acompanha componentes diversos da tonalidade harmônica. Outros dispositivos moderno-contemporâneos que poderiam, rapidamente, ilustrar o argumento seriam, por ex.: A propagação da dominante (o $\mathbf{V}^{7}$ principal) para a ideia de dominante secundária que inflaciona a tonalidade com diversos outros $\mathbf{V}^{\mathbf{7}}$. 0 acorde diminuto que se transfere do locus especifico do VII grau do modo menor (escala harmônica) para diversos outros locais do sistema (inclusive da tonalidade maior). 0 acorde de sexta aumentada (SubV'), a princípio reservado para a função dominante da dominante no modo menor que se expande, generalizando o recurso para incontáveis pontos de preparação. 0 acorde de sexta napolitana (bll), original de uma mutação da tonalidade menor que empresta seu efeito diferenciado à tonalidade maior (como 
$\mathrm{blI}^{7 \mathrm{M}}$ ou como bVII ${ }^{7 \mathrm{M}}$ ). As vizinhanças de terceira (mediantes, submediantes) raras e especiais (i.e. inexplicáveis) nos séculos XVII e XVIII que se tornaram estereótipos até banais ao longo dos séculos XIX e XX. Dispositivos da época da "saturação da tonalidade" ou "pós-tonais" (tais como o "acorde de Tristão", o "acorde de Scriabin", o "modo de Liszt", a "escala de tons inteiros", a "escala octatônica", os acordes por superposição de quartas, etc.), também passam por esse tipo de processo e crítica quando ganham uso na música popular urbana.

23 Sobre a noção de decoro como um princípio básico não só da música, mas de toda a conduta humana no século XVIII ver o estudo de LUCAS (2003).

24 A arguta tese de que a música alemã solidifica a "experiência conjunta de toda a Europa" foi enunciada pelo compositor e flautista alemão Johann Joaquim Quantz (1697-1773) em 1752: "Num estilo que, como o da Alemanha atual, consiste numa mistura dos estilos dos diferentes povos, cada nação encontra alguma coisa com que tem afinidades". Para Quantz, a música da Alemanha é "mais universal e mais agradável", pois conjuga e mistura os bons elementos da "pura música italiana", que já não se assenta "sobre fundamentos tão sólidos como outrora", e do "puro estilo francês" que "permaneceu excessivamente simples" (QUANTZ apud GROUT e PALISCA, 1994, p.477). 0 bordão que apregoa J. S. Bach como uma espécie de "ponto de partida" da música moderno-contemporânea, possui inúmeros registros. Conforme BENÉVOLO (2004, p.61-62), para o teórico e historiador Johann Nikolaus Forkel (1741-1818), primeiro biógrafo de Bach e o primeiro a lutar pelo reconhecimento da sua genialidade postumamente, Bach é o "príncipe dos clássicos passados e futuros". Em um contexto de soerguimento nacionalista, Forkel declara a arte de Bach como um "tesouro inigualável exclusivamente alemão" e dedica a sua biografia aos "admiradores patrióticos da verdadeira arte musical". Conforme KATER, Beethoven teria dito: "Bach não é um riacho, é um oceano!" Um jogo com a palavra "bach" que em alemão significa riacho (In: WEBERN, 1984, p.89). Para Debussy, Bach é o "ancestral de qualquer música" (DEBUSSY, 1989, p.194). Para Anton Webern (1883-1945) "tudo acontece em Bach", "tudo o que veio após Bach já estava em preparação [...]". "Aliás, Bach compôs de todas as maneiras possiveis, ocupou-se de tudo que pode ser pensado!" (WEBERN, 1984, p.82, 66 e 84). Sobre a invenção de J. S. Bach como um dos pilares supremos do reino do espírito alemão, uma espécie de "essência hereditária de um grande passado", ver o estudo de DAHLHAUS (1999, p.116-125). No momento de nacionalização da música brasileira, ecos desse culto ao nome de Bach (um mestre das sincopas) vão repercutir em nosso entorno. No seu Ensaio sobre a música brasileira, de 1928, Mário de Andrade (1893-1945) vê Bach (e também Haydn e Mozart) como um "espírito totalmente universal" (ANDRADE, 2006, p.14), e no capitulo intitulado "Polifonia" declara: "a harmonização europeia é vaga e desraçada". Nos anos de 1930 a 1945, nesse mesmo contexto de invenção de um nacionalismo brasileiro e moderno, Heitor Villa-Lobos (1887-1959) compõe as célebres Bacchianas Brasileiras expondo artisticamente sua percepção de possiveis afinidades entre a música popular (sincopada) que se fazia no Brasil e a música de Bach.

250 Ex.11a é citado em BARTEL (1997, p.404), o Ex.11b em PISTON (1998, p.54) e o Ex.11d em LA MOTTE (1988, p.58). Tais autores trazem uma vasta coleção de exemplos minimamente referenciada aqui.

260 Ex.12a é citado em PISTON (1998, p.85); o Ex.12b em KENNAN (1978, p.71-72); o Ex.12c em PISTON (1998, p.64); o Ex.12d em KENNAN (1978, p.66) e PISTON (1998, p.74).

27 Sobre o sentido dos termos "distinção" e "capital" (artístico, social, cultural, simbólico, linguístico, escolar, etc,) no vocabulário teórico colocado pelo sociólogo Pierre Bourdieu, ver BOURDIEU (2007), SHUKER (1999) e VALLE (2008). Sobre o sentido dos termos agudeza e engenho na crítica musical setecentista, ver LUCAS (2007).

28 Leia-se, como documento datado, um trecho escolhido no verbete Síncope do Dicionário da Música do "musicólogo" francês Michel Brenet (pseudônimo de mademoiselle Marie Bobillier, 1858-1918):

Modernamente, graças à música chamada negra e o sucesso alcançado pelas pequenas orquestras de jazz, convertidas em veículos de transmissão da música dançante procedente da América do Norte, a sincope é algo consubstancial dessa música. A origem das complicadas combinações de ritmos onde a forma sincopada adquire extraordinária preponderância, se encontra nas formas primárias da música própria dos povos africanos que há alguns séculos foram levados à América. Em todos os povos de civilização rudimentar, um dos valores substantivos da música é o ritmo. Os cantos, como as danças populares, oferecem sucessões e combinações de ritmos diversos nos quais reside o grande interesse que aos indigenas naturais despertam suas músicas. Dai, pois, que os negros, hoje completamente aclimatados e naturalizados em terras americanas, e particularmente na América do Norte, por lei inevitável de atavismo racial, cantem e produzam sua música conservando em sua lírica a modalidade das escalas pentatônicas africanas e a tendência a fazer do ritmo um meio expressivo. Na música popular e nas danças americanas, as fórmulas sincopadas adquiriram um grau insuspeitável de riqueza desde há pouco mais de meio século. A síncope se transformou em elemento essencial da música de dança. Os cake-walks e os foxtrotes não são outra coisa que combinações de ritmos nas quais se faz todas as formas de síncope imagináveis que por superposição ou por cruzamento umas com as outras, produzem aspectos dinâmicos de irresistivel efeito (BRENET, 1962, p.478).

29 Com o termo "campo", Bordieu se refere a espaços especificos de posições sociais nos quais um determinado bem é produzido, consumido e classificado. 0 campo se particulariza [...] como um espaço onde se manifestam relações de poder, o que implica afirmar que ele se estrutura a partir da distribuição desigual de um quantum social [capital social] que determina a posição que um agente específico ocupa em seu seio. [...] A estrutura do campo pode ser apreendida tomando-se por referência dois pólos opostos: o dos dominantes e os dos dominados. Os agentes que ocupam o primeiro pólo são justamente aqueles que possuem um máximo de capital social; em contrapartida, aqueles que se situam no pólo dominado se definem pela ausência ou pela raridade do capital social especifico que determina o espaço em questão (ORTIZ, 1983, p.21). No "campo", os agentes (individuos ou instituições) que ocupam a posição dominante tendem a adotar estratégias conservadoras ou ortodoxas que visam manter (canonizar) os valores que Ihes são favoráveis. Os agentes que ocupam posições inferiores no interior do campo (i.e., aceitam a hierarquia do campo) tendem a adotar estratégias que objetivam alcançar os padrões de excelência dominantes ou a adotar estratégias heterodoxas ou heréticas que visam a contestação e a subversão das estruturas hierárquicas vigentes. "A estratégia dos agentes se orienta, portanto, em função da posição [atual e potencial] que eles detêm no interior do campo, a ação se realizando sempre no sentido da 'maximização'" dos capitais (ORTIZ, 1983, p.22). Basicamente, o que está em jogo nesse "campo" da música popular são relações de poder entre o que é a "boa" e a "má" música, "quem é" o "grande músico" e "quem não é", e "quem são" os "autorizados" a julgar (classificar, hierarquizar) os bens da música popular. Cf. BOURDIEU (2007), CAVALCANTI $(2007$, p.19) e VALLE $(2008$, p.105).

30 Sobre esta temática ver o estudo de CAVALCANTI (2007).

31 As harmonias do Ex. 13b e 13c baseiam-se nas cifras de Edmilson Capelupi. 0 fragmento 13e foi retirado das transcrições de PRANDINI (1996, p.72).

Sérgio Paulo Ribeiro de Freitas é professor da Universidade do Estado de Santa Catarina - UDESC (Florianópolis) atuando nas áreas de teoria da música, harmonia tonal, contraponto e análise musical. Atualmente é aluno do Doutorado em Música da UNICAMP onde desenvolve pesquisa na área de Fundamentos Teóricos da Música Popular. 